\title{
KENTSEL DÖNÜŞÜM VE DIYYRBAKIR SUR ÖRNEĞİ
}

\author{
Dr. Öğr. Üyesi Ahmet KAYAN \\ Harran Üniversitesi, İ̈BF, (akayan2002@gmail.com)
}

\begin{abstract}
ÖZET
Kentsel dönüşüm, kentlerin zamanla eskiyen, yıpranan, çürüyen, yaşanılamaz duruma gelen yapıların yıkılarak yerine yeni, çă̆daş ve yaşanabilir mekanların yapılması süreci olarak belirtilebilir. Türkiye 1950'li yullardan itibaren hızll kentleşme sürecine girmesine răgmen, Diyarbakır 1980'li yıllardan itibaren hızlı kentleşme sürecine girmiştir. Hızlı kentleşme süreciyle birlikte kırsal kesimden gelen yoksul ve dar gelirli vatandaşlar barınma sorununu gecekondular yaparak gidermeye çalışmıştır. Bu gelişmeler neticesinde Surların içi kısa sürede plansız, düzensiz, kaçak yapı ve gecekondularla dolmuştur. İşte suriçinde bozulan ve kullanılamayacak duruma gelen tarihi ve kültürel eserler ile kaçak yapı ve gecekonduların önüne geçmek, bunların onarlarak aslına uygun hale getirmesini sağlamak için burada kentsel dönüşüm uygulamaları bir ihtiyaç haline gelmiştir. Bu çalışmada, dünyada ve Türkiye'de kentsel dönüşüm uygulamalarının tarihsel gelişimi, kentsel dönüşümün amaçlart ve yöntemleri anlatılarak kentsel dönüşüm projelerine bütüncül bir yaklaşım sergilemek istenmiştir. Bu kapsamda Diyarbakır Sur İlçesi kentsel dönüşüm uygulamaları, bu projenin uygulanmast sürecinde karşılaşılan güçlükler ile Sur ilçesi kentsel dönüşüm uygulamalarında gelinen son durum anlatılmıştır.

Anahtar Kelimeler: Kent, Kentsel Dönüşüm, Sit Alanı, Kentsel Dönüsüm Yöntemleri.
\end{abstract}

\section{URBAN TRANSFORMATION AND THE CASE OF THE DISTRICT OF SUR IN DIYYARBAKIR}

\begin{abstract}
Urban transformation can be defined as the process of demolishing the buildings in cities that have becomeold, worn of anddecayed, andthus have become inhabitable, andconstructing new, modern andlivables paces in their place. Although Turkey entered into a rapidurbanization process beginning in 1950s, Diyarbakur entered into that processonly in 1980s. With the start of the rapidurbanization process, poorand low-income families tried to solve their accommodation problem by buildings hacks. As a result of these developments, the are awithin the city walls was filled in a short time with shantyand ille gal building sandshacks. Thus, urban transformation practices have become a necessity in orderto restore the historical and cultural Works that have decayedand become unusableand topreventthe illegal buildings and shacks in the walled city area. Inthepresentstudy, it has been aimed to explain the historical development of urban transformation practices in the worldand in Turkey, and to demonstrate a holistic approachto urban transformation projects. The presentstudy has addressed the subject of urban transformation, the development of urban transformation in the worldand in Turkey, the objectives and methods of urban transformation, the urban transformation practices in the district of Sur in Diyarbakur, the difficulties encounteredduring the process of the implementation of that Project and thecurrentstatus of the urban transformation in the district of Sur.
\end{abstract}

Keywords: City, Urban Transformation, Protected Area, Urban Transformation Methods. 


\section{Giriş}

Ekonomik, sosyal ve fiziksel olarak doğal yapısı bozulmuş kent yerleşimlerindeki yapıların günün şartlarına göre onarılarak sağlıklı yerleşimlere dönüştürülmesi işlemleri kentsel dönüşüm olarak belirtilebilir. Kentsel dönüşüm projeleri hem dünyada hem de Türkiye'de kentsel yenileme amacıyla uygulanmaktadır. Dünyada 1900'lı yılların başında Sanayi Devriminden sonra kentlerin etrafındaki sanayi bölgelerinde ortaya çıkan yoksulluk yuvalarının ortadan kaldırılması, yerine modern ve çağdaş yapıların yapılması için kentsel dönüşüm projeleri uygulanmıştır. Ayrıca Birinci ve İkinci Dünya Savaşları'nda yıkılan, yakılan kentsel yapılar ve alt yapının yenilenmesi amacıyla kentsel dönüşüm projeleri uygulanmıştır. Türkiye'de 1950'li yıllarda başlayan hızlı kentleşme süreci sonunda kentlerde biriken gecekonduların ve kaçak yapıların ortadan kaldırılması, bunların yerine çağdaş ve yaşanılabilir yapıların yapılması amacıyla 1990'lı yıllardan itibaren kentsel dönüşüm projeleri uygulamaya başlanmıştır. Ülkemizde 1990'lı yıllarda büyükşehir belediyelerinin münferit olarak uygulamaya çalıştı̆̆ kentsel dönüşüm projeleri 2000'li yılların başında yasal dayanağa kavuşturularak bütün belediyelerin kentsel dönüşüm projeleri yapmanın önü açılmıştır.

Türkiye 1950'li yıllarda hızlı kentleşme sürecine girdiği halde Diyarbakır 1980'li yıllardan itibaren hızlı kentleşme sürecine girmiştir. Bu nedenle Türkiye' de 1990'lı yıllarda kentsel dönüşüm projeleri uygulamasına rağmen Diyarbakır'da 2008 yılında ilk kentsel dönüşüm projesi uygulamaya başlanmıştır. Diyarbakır Sur ilçesindeki kentsel dönüşüm projesinin amacı hem içinde yaşanılamayacak derecede risk azr eden gecekondu ve kaçak yapıları ortadan kaldırarak yerine çağdaş ve yaşanılabilir konutlar yapmak hem de birçok medeniyete ev sahipliği yapan Diyarbakırdaki tarihi, kültürel ve antik eserleri onararak korumasını sağlamaktır. Bu çalışmada kentsel dönüşüm kavramı, kentsel dönüşümün hangi amaçlarla uygulandığı, belli başı kentsel dönüşüm yöntemleri anlatıldıktan sonra Sanayi Devrimi ve Birinci ve İkinci Dünya Savaşı'ndan sonra dünyada uygulanan kentsel dönüşüm uygulamaları anlatılmıştır. Daha sonra Türkiye'de kentsel dönüşümün gelişimi, kentsel dönüşümün yasal dayanakları ve kentsel dönüşümün aktörleri açıklanmıştır. Kentsel dönüşümün gelişimi ve genel çerçevesi belirtildikten sonra Diyarbakır Sur İlçesinde kentsel dönüşüm uygulanmasının gelişimi ayrıntılı olarak anlatılmıştır. Ayrıca Sur ilçesi kentsel dönüşüm projesi kapsamında surların içinde kalan riskli alanlar, riskli yapılar ve rezerv alanlar belirtildikten sonra 2008 yılında başlanan ama 2012 yılında istem dışı nedenlerle durdurulan, 2015 yılındaki güvenlik/ terör olaylarındanki gelişmelerden sonra 2016 yılında ikinci kez uygulamaya konulan Suriçi Kentsel Dönüşüm Projesinde gelinen son durum da anlatılmıştır.

Diyarbakır Sur ilçesindeki (Suriçi Bölgesi) birçok tarihi, turistik, kültürel, dini ve antik eserler ile sivil mimariye ait çok sayıda konut, işyeri eskime, yıpranma ve çürümeden dolayı içinde yaşanılamayacak derecede tehlike arz etmekte, bu nedenle başta riskli yapılar olmak üzere Sur ilçesinin tamamında kentsel dönüşüme duyulan ihtiyaç çalışmanın problematiği olarak belirtilmiştir. Kentlerde zamanla yıpranan, eskiyen, çörüyen ve kullanılamaz duruma gelen tarihi, kültürel ve antik yapıların kentsel dönüşüm projeleriyle yıkılmaktan kurtarılabileceğini ve onarılarak topluma tekrar kazandırılabileceğini, ayrıca gecekondu ve kaçak yapıların kentsel dönüşüm projeleriyle ortadan kaldırılabileceği, bunların yerine yaşanılabilir modern ve çağdaş yapıların yapılabileceğini göstermeye çalışmak bu çalışmanın amacı olarak belirtilmiştir. Kentlerde içinde oturmak bakımından tehlikeli duruma gelen 
riskli yapı ve riskli alanlarda kentsel dönüşüm projelerinin uygulanması bir zorunluluktur. Tarihsel süreçte gelinen son noktada kentsel dönüşüm projelerinin kentlerde sadece gecekondu ve kaçak yapıların yenilenmesi amacıyla değil aynı zamanda kentlerde sosyal ve ekonomik canlanmayı sağlamak amacıyla da uygulandığını göstermek bu çalışmanın başka bir amacıdır. $\mathrm{Bu}$ çalışmanın kuramsal temelleri için öncelikle literatür taraması yapılmıştır. Daha sonra bu alandaki ampirik çalışmaların sonuçları ve güncel istatistiki veriler derlenmiştir. Dolayısıyla bu çalışma ilgili literatür çalışması ve bu alandaki ampirik çalışma sonuçları ve güncel istatiski verilerden yararlanılarak yapılmıştır.

\section{Kentsel Dönüşüm Kavramı}

Türk Dil Kurumunun hazırladığı sözlükte dönüşüm kelimesi, olduğundan başka bir şekle girme, inkılâp, tahavvül etme ve şekil değiştirme olarak tanımlanmaktadır (Yenice, 2014: 77).

Kentsel dönüşüm; kentsel gelişmenin, sosyal, iktisadi ve mekânsal anlamda yeniden ele alındığ ${ }_{1}$ ve kentlerdeki sorunlu bölgelerin sağlıklı ve yaşanabilir hale getirilmesi için yıkılıp yeniden inşa edilmesi, canlılık kazandırılması ve sağlıklaştırılması için projeler üretilip bunların uygulanmasıdır (Ertaş, 2011: 2-3).

Kentsel dönüşüm, kentlerdeki problemleri çözebilmek üzere, değişime uğramış bir yerin iktisadi, fiziki, toplumsal ve çevresel şartlarına kalıcı bir çözüm sağlamak için yapılan kapsamlı bir çalışma ve uygulama şekli olarak ifade edilebilir (Şişman \& Kibaroğlu, 2009: 1).

Kentsel dönüşüm kısaca, kaybedilen bir ekonomik etkinliğinin yeniden canlandırılması ve geliştirilmesi,çalışmayan bir toplumsal işlevin yeniden çalışır duruma getirilmesi, dışlanmış alanlarda, yeniden bütünleşmenin sağlanması, çevre dengesinin ve çevresel kalitenin yok olduğu yerlerde, bu dengenin yeniden sağlanması olarak belirtilebilir (Keleş, 1998:25).

Günümüzde kentsel dönüşüm tüm dünyada geleceğe yönelik toplumsal öngörülerin oluşturulması ve geleceğin yönetilmesi süreci olarak ele alınmakta, bu nedenle kentsel dönüşüm sosyal, ekonomik, çevresel ve mekânsal gelişmenin bir bütün olarak ele alınması gerektiği belirtilmektedir (İMO, 2017: 11).

İlk uygulanmaya başladığında daha çok gecekondu ve benzeri yapıların ortadan kaldırılması için uygulanan kentsel dönüşüm uygulamaları günümüzde toplumun ekonomik ve sosyal yönden gelişmesi ve canlanması için de uygulanmaktadır (Tektaş, 2019).

\section{Kentsel Dönüşümün Dünyada Gelişimi}

Kentsel dönüşüm kavramının ilk ortaya çıktığı Batılı ülkelerin dönüşüm süreciyle ilgili deneyimlerine bakıldığında kentsel dönüşüm olgusunun farklı aşamalardan geçtikten sonra kentsel politikalarda yer aldığ 1 görülmektedir. Kentlerde oluşan fiziki, sosyal ya da iktisadi sorunlara karşı üretilen çözümler, kentsel dönüşüm sürecini başlatan etkenlerdir. Dünya'da gerçekleşen kentsel dönüşümü asıl motive eden güç, üretim tarzının değişimidir. 18. Yüzyılın ortalarından itibaren İngiltere'de başlayan sanayi devrimiyle geleneksel tarım toplumundan sanayi toplumuna ve üretim tarzına geçilmesiyle, kentlerde kurulan fabrikalarda çalışmak için gelen işçi göçü, kentleri yeniden biçimlendirmiştir (Aktay vd., 2012: 3). Sanayi Devrimiyle 
gelişen kentlere kırsal alandan yapılan kitlesel göçler, başta İngiltere, Fransa ve Almanya olmak üzere Batı Avrupa ülkeleri ve Kuzey Amerika'da kentlerde nüfusun hızla artmasına yol açmış, bu nüfus yoğunluğuyla birlikte altyapı, konut, ulaşım ve çevre sorunları gelişmiştir. Avrupadaki büyük kentlerde işçi sınıfının içinde bulunduğu insanlık dışı koşullar, birçok düşünürü ve plancıyı etkilemiş, bu etkileme sonucu Avrupa'da kentsel dönüşüm fikrinin ortaya çıkmasına yol açmıştır (Öngören \& Çolak, 2013: 20).

Avrupa ülkelerinde kentlerde çöküntüye yol açan diğer önemli bir faktör de Birinci ve İkinci Dünya Savaşlarıdır. Savaşta bombalama sonucu yıkılan şehirlerin yeniden inşası ve canlandırılması gereği dönüşüm tartışmalarını beraberinde getirmiştir. Savaş’ta çok büyük zarar gören ve tarihi zenginlikleri dolayısıyla önemli olan kentlerde yaşanan çöküntü ilgilileri çözüm arayışına itmiştir (Aydınlı, 2012: 64). Savaştan sonra Avrupa kentlerinin yeniden imarı için yabancı ülkelerden bu ülkelere işçi göçü başlamıştır. Bu yıllarda başlayan Avrupa'ya yabancı göçlerle birlikte şehirler üzerinde nüfus baskısı artmış ve çözüm olarak banliyöler kurulmuştur (Aktay vd., 2012: 4).

Amerika Birleşik Devletleri, "New Heaven” kentini yenilemek, Almanya, 2. Dünya Savaşı'nın ve Hitler'in izini silebilmek, İngiltere endüstri devriminin etkisiyle ortaya çıkan şehirlerini yaşanılabilir hâle dönüştürebilmek, Fransa, ülkesindeki isyanları engellemek ve kontrol altına alabilmek amacıyla kentsel dönüşüm projelerini uygulamıştır (Demirkıran, 2008: 12).

Kentsel dönüşüm projelerinde 1960 ve 1970’li yıllarda kentsel iyileştirmeye öncelik verilirken 1980'li yıllarda kentlerin ekonomik olarak canlandırılmasına öncelik verilmiştir. 1990'lı yıllarda ise kentsel iyileştirme ve yeniden canlandırma yöntemleri uygulanmıştır. 2000'li yıllarda kamu ve özel sektörün yanısıra sivil toplum kuruluşlarının da bu projelere katılmaları için merkezi ve yerel yönetim tarafından teşvik edilmiştir (Öngören \&Çolak, 2013: 22).

Kentsel dönüşümün gelişimi, çeşitli dönemlere ayrılmakla birlikte genel olarak dört döneme ayırmak ve incelemek mümkündür. Bu dönemler kısaca şöyle belirtilebilir (Demirkıran, 2008: 12-13):

1. Kentlerin Yeniden İnşası ve Sanayileşme Dönemi: Avrupa'da Endüstri Devrimi sonrasında ortaya çıkan işçi şehirlerinin acınası hali ve yaşam şartlarının kötülüğü 19101940 yılları arasında aydınlar tarafından tartışılmış ve bu tartışmalar neticesinde kentsel dönüşüm düşüncesinin alt yapısı oluşmuştur (Üstün, 2009: 14). Ayrıca bu tartışma ve gelişmeler kentsel dönüşüm uygulamalarının yaygın hale gelmesine yol açmıştır. $\mathrm{Bu}$ tartı̧̧ma ve gelişmeler neticesinde yukarıda da belirtildiği gibi Amerika Birleşik Devletleri'nde, Almanya'da, İngiltere ve Fransa'da kentsel dönüşümün ilk örnekleri ortaya çıkmıştır. Bu dönem aynı zamanda Batılı ülkelerde başta askeri sanayi olmak üzere sanayileşmenin hızla geliştiği yıllardır. Sanayi Devrimindeki ilk dönemin aksine bu dönemde Sanayileşmeyle birlikte gelişen kentleşmenin planlı ve düzenli olması istenmiştir.

2. Kentlerin İkinci Dünya Savaşı Sonrasında Yeniden İnşası ve Sanayinin Desantralizasyonu Dönemi: Kentsel dönüşümde bu zaman dilimi 1940-1960 yılları arasındaki süreyi kapsar. 
1950'li yıllarda İkinci Dünya Savaşının izleri silinmeye çalışılırken "Buldozer Dönemi” olarak nitelendirilen bu dönemde, daha önce işçiler için yapılan ve "slum" olarak bilinen sefalet yuvaları vardı. Daha sonra bu sefalet yuvalarının tümünün yıkılmasıyla bu alanda ilk kentsel yenileme çalışmaları başlamıştır. Yani bu dönemde bütün bir alanın yıkılarak yerine her şeyi ile yeni bir kentin inşa edilmesi politikası izlenmiştir (Öngören, 2013: 13). Ayrıca sanayinin belli kentlerde yoğunlaşması yerine ülke genelinde kentler arasında yaygınlaştırılması yoluna gidilmiştir. İngiltere'nin 1940'lı yıllarda yeni kentler yasasını çıkarması ve Londra çevresinde yeni kentlerin kurulması için kentsel planlama yapması çalışmaları bu duruma örnek olarak gösterilebilir.

3. Fiziki Müdahaleler Dönemi: 1960-1980 yılları arasını kapsayan bu dönemde, bir bölgenin komple yıkılıp yerine tekrardan yenisinin inşa edilmesinin maliyetinin yüksek olmasından dolayı kentlerin belli bölgelerinde iyileştirme çalışmaları genel olarak tercih edilmiş ve uygulanmıştır. Sanayi kuruluşlarının belli kentlerde ve belli bölgelerde toplanması yerine ülke ya da bölge düzeyinde her tarafa yayılmasına paralel olarak kentsel dönüşüm kapsamında kentsel müdahaleler de yaygın olarak yapılmıştır (Demirkıran, 2008: 13).

4. Kentsel Yenileme Dönemi: 1980 sonrasında büyük yapı bölgelerinde (büyükşehir) görülen sorunlar sebebiyle kent yenileme düşüncelerinin ortaya atıldığı ve kentsel dönüşüm politikalarının oluşturulduğu yenileme çalışmalarının, iktisadi, mekânsal ve toplumsal bakımdan bir bütün olarak ele alındığı bir dönemdir. 1980'li yıllarda dünya genelinde görülen liberalleşme politikalarının da etkisiyle ulusal sermayenin yanında uluslararası sermeye de (özellikle rant değeri yüksek alanlarda) kentsel dönüşüm politikalarında etkili olmuştur. Kentsel yenileme ile bazen sorunlu bir kentin tamamı yenileme kapsamına alındığı gibi bazen de kentin tamamını yıkıp yeniden yapmak pahalı bir yöntem olduğu için kentlerin sorunlu bölgelerinde kentsel dönüşüm projelerinin uygulanması yoluna gidilmiştir (Öngören, 2013: 14).

\section{Kentsel Dönüşümün Amaçları}

Kentsel dönüşüm uygulamaları, kent halkının iltisadi, fizik ve sosyal geleceği üzerinde etkili olabilmektedir (Yaman, 2014: 14). Bu nedenle kentsel dönüşüm uygulamalarında şu beş temel amaca dikkat edilerek tasarlanması gerektiği belirtilmektedir (Şişman \& Kibaroğlu, 2009: 2).

1. Kentin fiziki yapısıyla sosyal sorunları arasında direkt bir ilişkinin kurulması ve bu projelerin temelde toplumsal bozulmanın önüne geçecek şekilde geliştirilmesi gerekir. $\mathrm{Bu}$ kapsamda kentlerdeki önemli sorunların başında gelen gecekondu yapımının engellenmesi, var olanların ortadan kaldırılarak yerine sosyal donatılarıyla çağdaş yapıların yapılması, gecekondulardaki mülk sahiplerinin de desteğini alarak yeni alternatifler öneren, kentsel dönüşüm uygulamalarının hayata geçirilmesi sağlanmalıdır (Görün\&Kara, 2010: 153).

2. Kentsel dönüşüm projeleri, kentinlerin çabuk büyüyen, değişen ve bozulan dokusunu korumayı ve yeni ekonomik, toplumsal, fiziksel, çevresel ve altyapısal ihtiyaçlara göre gelişen değişim ihtiyacını karşılamalıdır. Bu çerçevede kentsel alanları temizlemek, 
düzenlemek, tabi afet ve rizikolara karşı güvenli duruma getirmek kentsel dönüşümün başka bir amacıdır (Şişman \& Kibaroğlu, 2009: 9).

3. Kentsel dönüşüm uygulamaları, kentlerdeki fiziki ve sosyal alanları tehdit eden çöküntü alanlarının yeniden canlandırılması ve iktisadi hareketliliği getirecek stratejileri geliştirerek kentsel refah ve yaşam kalitesini artırmayı hedeflemelidir. Kentsel dönüşüm projeleriyle özellikle sosyal boyutlar gözetilerek, ilgili bölge insanlarının refah ve yaşam kalitesini artıracak bir yaklaşımlaele alınması gerekir (Şişman \& Kibaroğlu, 2009: 2).

4. Kentsel dönüşümle, kentsel alanların çok ekin bir şekilde kullanımı ve luzumsuz yere kentsel genişlemeden kaçınmaya yönelik stratejiler ortaya koyacak projeler geliştirilmelidir. Kent sakinlerinin mağdur edilmemesi, düşük ve orta gelir düzeyine sahip kesimin konut edinme imkânlarının iyileştirilmesi, kentsel alanların gelişigüzel büyüme anlayışına son verecek, yeni stratejilerin planlı bir biçimde ortaya konulması amaçlanmalıdır (Gümüşboğa, 2009: 3).

5. Kentsel dönüşüm, sosyal yapı ve politika aktörlerin ürünü olarak kentsel politikaları şekillendirme ihtiyacını karşılamayı ve çok katılımlı bir planlama ve tasarım süreci ile gerçekleştirilmesi hedeflemelidir. Ancak kentsel dönüşümde kentlerin özgün kimliğini kayb etmemesine, kentsel yapılarda sürdürülebilirliğin gözetilmesine dikkat edilmelidir (Yaman, 2014:14).

Kentsel dönüşümün temel hedefi kentlerde yaşanan çöküşü engellemektir. Bunun yanında geçmişten bugüne kadar kültür mirası şeklinde gelen tarihsel dokuların varlıklarını sürdürebilmesini sağlamak da yine kentsel dönüşümün temel hedefleri arasındadır. Kentlerde çöküşü önlemeye ve yeniden imara yönelik her hedefi kentsel dönüşüm hedefleri arasında belirtmek mümkündür (Bayraktar,2006: 235). K1saca kente yönelik ekonomik, sosyal, kültürel, fiziksel gibi bütün işlerin planlı ve programlı bir biçimde yürütülmesini sağlayabilecek bir düzene oturtulması işlevleri, kentsel dönüşüm faaliyetleri içerisinde incelemek mümkündür (Kuzu, 2004: 253).

\section{Kentsel Dönüşüm Yöntemleri}

Tarihsel süreçte ülkelerin gelişmişlik seviyesine ve uygulama durumuna göre farkılık arz etmesine rağmen belli başlı kentsel dönüşüm yöntemlerini aşağıdaki gibi belirtmek mümkündür (Öngören\&Çolak, 2013: 27):

\subsection{Kentsel Yenileme (Urban Renewal)}

Kentsel yenileme bazı kaynaklarda gecekondu yenileme, iyileştirme ve temizleme gibi spesifik anlamlarda kullanılmakta ve yeniden geliştirme, rehabilitasyon ve koruma eylemlerini içermektedir. Bu kavramlar aynı zamanda kentsel dönüşümü ifade etmek için de kullanılmaktadır. Kentsel yenileme hâlihazırdaki bozulan kentlerin ve kent merkezlerinin reforme etmek ve çağın gereklerine ayak uydurmak için yeniden planlanması ve bunun uygulanması olarak tanımlanır. Kentsel yenileme, yerleşme düzeni ve mevcut yapıların durumu bakımından yaşam ve sağlık şartlarının rehabilite edilmesi imkanı olmayan alanlardaki yapıların tümü ya da bir kısmının ortadan kaldırılarak yeniden imar edilmesi süreci olarak belirtilebilir (Görün \& Kara, 2010: 145). 


\subsection{Kentsel Yeniden Canlandırma (Urban Revitalization)}

Yeniden canlandırma ile ekonomik, fiziksel veya sosyo-kültürel açılardan çöküntü içinde olan kent mekânı, çöküntüye yol açan etkenlerin değiştirilmesi veya ortadan kaldırılması sonucunda yeniden hayata döndürülmesi sağlanır (Üstün, 2009: 6). İlk canlılı̆̆1 kaybolmuş mekanların, özellikle tarihi kent merkezlerin alınacak sosyal tedbirlerle yeniden canlılık kazanmasını sağlamak yeniden canlandırma olarak belirtilmektedir. İngilizce "revitalization" kelimesinin Türkçedeki karşılığg olarak "yeniden canlandırma” sosyal, kültürel, iktisadi ya da fizikselbakımdan bir çöküntü içinde olan kentlerin çöküntüye neden olan bölgelerinin ortadan kaldırılması ya da değiştirilmesi sonucunda sözkonusu bölgenin tekrar hayata döndürülmesidir (Gümüşboğa, 2009: 9).

\subsection{Kentsel Koruma (Urban Conservation)}

$\mathrm{Bu}$ yöntemle kentlerdeki kültürel ve doğal taşınmaz varlıklar yasal düzenlemelerle korumaya alınır. Böylece, tarihsel yapı mirasının günümüz yaşamı ile bütünleştirilmesi sağlanır. Koruyucu bir bakış açısına sahip olan kentsel korumaya tarihi açıdan bakıldığında kentlerde birincil koruma yöntemi olarak ortaya çıkmaktadır. Kentsel koruma, özgün niteliğiyle koruma ve sınırlı değişimle koruma olmak üzere iki çeşit korumayı içermektedir. Özgün niteliğiyle koruma yapıların özgünlüklerine zarar vermeden korumayı ifade etmekte, sınırlı değişimle koruma ise yapıların, iktisadi kullanımında kalmasını sağlamak üzere karakterin ve ölçeğin korunarak günün şartlarına uyarlanmasını ifade etmektedir. Kentsel korumayle toplumun geçmişteki ekonomik ve sosyal şartlarını, kültürel değerlerini yansıtan fiziki yapının, yaşanan değişim ve gelişmelerden dolayı yok olmaktan kurtarılması,kültürel varlıkların topluma yararlı, ekonomik ve işlevsel hale getirilmesi hedeflenmektedir (Ertaş, 2011: 4).

\subsection{Entegrasyon (Integration)}

$\mathrm{Bu}$ yöntemle amaçlanan, kentin kimliğini korurken, hâlihazırdaki binaların yanında başka yeni binaların katılmasıyla zengin bir görünüm kazandırılmasıdır. Bölgenin asıl sakinleri, bu bölgeyi terk etmeyerek kentsel dönüşüme katkıda bulunmaktadır. Kentlerde yapılacak olan değişikliklere halkın katılımı öngörülmekte ve dönüşüm yapılacak mekanın, o yerde yaşayanlarla birlikte ele alınması ve o mekanların değerleri ile kentsel yaşam değerlerinin uzlaştırılması hedeflenmektedir (Polat \& Dostoğlu, 2007: 63). Bu yöntem sayesinde bozulmuş, kullanılamaz duruma gelen kentlerin ilgili kısımları yeniden yapılandırılarak ekonomik, sosyal ve kültürel yönden kentle bütünleştirilmesi sağlanmaktadır.

\subsection{Soylulaştırma (Gentrification)}

Bu yöntem kent merkezinde kalan ama eskimiş, köhneleşmiş ve içinde yaşanılamayacak derecede yıpranmış duruma gelen eski yapıların yıkılarak yerine modern konut ve sosyal donatı alanların yapılması ve buralara zengin kesimin yerleşmesi süreci olarak belirtilmektedir. Soylulaştırma sonucunda sosyo-kültürel açıdan çöküntü yaşayan ve dolayısıyla fiziksel anlamda çevresi de bozulan kentsel alanların sosyo-kültürel yapısının ıslahı sağlanır (Özden, 2006: 258). 
Soylulaştırma yöntemini, değerli kentsel alanların daha üst gelir grupları tarafından ele geçirilmesi süreci olarak değerlendirenler devardır. Soylulaştırma, sosyo-kültürel açıdan bozulmuş, köhneleşmiş, dolayısıyla fiziksel çevresi çökmüş alanlarda, özellikle de tarihi kent kısımlarında sosyal yapının geliştirilmesi süreci olarak ifade edilmektedir (Ertaş, 2011: 5). Bazı görüşlere göre soylulaştırma, yerinden edilme sürecini içerdiği için bilim adamları, yerel yönetimler ve halk arasında yoğun tartışmalara neden olmaktadır.

\subsection{Sağlıklaştırma (Sanitation)}

Sağlıklaştırma yöntemiyle eskimiş, performansı düşmüş, altyapıları yetersiz duruma gelmiş bir bölgenin performansı yeni yatırımlarla yeterli hale getirilmeye çalışılır (Tekeli, 2011: 276). Bu yöntem 19. Yüzyılda İngiltere'de yoksul kitlelerin yaşadıkları yerlerden sürülme ve slum temizleme aracı olarak belirtilmiştir. Sağlıklaştırma bir taraftan da toplumun temelindeki yenileştirmeyle, en yoksul bölgelerde yaşayan vatandaşların yaşam koşullarının iyileştirilmesine yöneliktir. Diğer taraftan da kentsel alanların çevresel performansını iyileştirmeyi amaçlayan tedbirler ve doğal-tarihsel olarak yapılaşmış çevrenin korunması şeklinde, kent yapılaşmasının olumsuz çevresel etkilerini azaltırken, kent ve kasabaların rekabet edebilirliğinin önünü açmaktadır (Gibson, 2007: 475).

\subsection{Eski Haline Getirme (Restore)}

Eski haline getirme yöntemiyle deformasyon başlamasına rağmen, özgün özelliklerini henüz yetirmemiş olan kentsel kısımların eski haline kavuşturulması amaçlanmaktadır (Özden, 2006: 258). Koruyucu eylem biçimlerinden olan kentsel iyileştirme/eski haline getirme, kentteki bir yerinbütününü veya bir bölümünü, işlevsizlikten kurtarmak, oturulabilecek özellikleri kalmamış ve eskimiş konut alanlarının daha yüksekişgörü ölçünlerine kavuşturmak olarak belirtilmektedir. Kentsel iyileştirmenin/eski haline getirmenin amacı, köhneleşmiş kentsel bölgelerin alınacak önlemlerle eski haline kavuşturulmasının sağlanmasıdır (Demirkıran, 2008: 34).

\subsection{Kentsel Yenileşme (Urban Renaissance)}

Kentsel dönüşüm uygulamalarında kullanılan yöntemler neticesinde, kentlerde kimlik kaybı, tek tip hale gelme gibi bazı eksikliklerin ortaya çıktığı görülmüştür. Bu tür olumsuz sonuçların belirginleşmeye başlamasıyla yeni bir kentsel dönüşüm uygulama yöntemi oluşturulması gerekliliği ortaya çıkmış, böylece kentsel yenileşme yönteminin temelleri atılmaya başlanmıştır. İngilizce "urban renaissance" kavramından Türkçeye geçen kentsel yenileşme kentte yapılacak olan değişikliklere halkın katılımını öngörmektedir (Demirkıran, 2008: 40-41).

Kentsel yenileşmenin hedefi sürekli canlılı̆̆ını koruyan kentler oluşturmaktır. Kentin içinde kültürel düzenlemeyle beraber ekonomik kalkınmaya da önem veren bir uygulamadır. Aslında dönüşüm içinde yer alan bireylerin dikkate alınmadığg ve ekonomik istikrarın düşünülmediği bir uygulamada, dönüşümden az bir süre sonra insanların o bölgede yaşamaktan vaz geçmesi ve ilgili alanın tekrar çöküntü haline gelmesi çok sık rastlanan bir sorun olmaktadır. Böyle problemlerin önlenmesi için kentsel yenileşmeyi önplanda tutan bütüncül sosyal ve kentsel dönüşüm politikaları tercih edilmelidir (Şen, 2018: 8). 


\section{Kentsel Dönüşümün Türkiye'de Gelişimi}

Türkiye Batı Avrupa ülkelerinin aksine geç sanayileştiği ve kentleştiği için kentsel dönüşüm projelerini de geç uygulamaya başlamıştır. Bununla birlikte kentsel dönüşüm konusunda Türkiye, özellikle mevzuat bakımından önemli yol almıştır. Türkiye'de kentsel dönüşümün gelişimi genel olarak üç dönem halinde incelenebilir (Ataöv\&Osmay, 2007: 60):

1. 1950-1980Arası Dönem: Türkiye'dehızlı kentleşme süreci 1950'li yıllardasanayileşmeye paralel olarak kırdan kente göçle başlamış, bu gelişmeyle birlikte kentlerde konut yetersizliği ve alt yapı sorunları ortaya çıkmaya başlamıştır (Ataöv\&Osmay, 2007: 63). $\mathrm{Bu}$ dönemde Türkiye toplumu köylü toplumdan kentli topluma, tarımsal üretimdem, sanayi üretimine doğru dönüşmeye başlamıştır. 1950'li ve 1960'lı yıllardan itibaren İstanbul, Ankara ve İzmir başta olmak üzere, diğer büyük kentlerin çoğu doğal, tarihsel, kültürel yapıyı ve afet risklerini gözardı edecek şekilde gelişmiştir (Keskinok, 2001: 37). Dünyada 1900'lu yılların başında kentsel dönüşüm uygulamaları ortaya çıkmasına rağmen ülkemizde bu dönemde kentsel dönüşüm projeleri somut ve yaygın olarak henüz uygulanmamiştır.

2. 1980-2000 Arası Dönem: Bu dönemde ekonomide dışa açılma, liberalleşme, küreselleşme ve yerelleşme olgusunun etkisi kentsel dönüşüm projelerine de yansımıştır. 1950-1960'lı yıllarda yapılan gecekondulara oy kaygısıyla ruhsat verilmiş, dolayısıyla ruhsatlı konutlarla ruhsatsız konutlar yan yana gelmiştir. Bu dönemde kentsel dönüşüm projeleri henüz yasalaşmamış olsa da bazı metropol kentlerin belediyeleri münferit olarak kentsel dönüm projeleri uygulamaya başlamıştır. Bu dönemdebaşkent Ankara' da, Ankara Büyükşehir Belediyesi öncülüğünde Portakal Çiçeği Vadisi ve Dikmen Vadisi kentsel dönüşüm projeleriuygulanarak kentsel dönüşüm alanında ilk proje ve ilk uygulama yapılmıştır (Yılmaz, 2015: 310).

3. 2000 Sonrası Dönem: Bu dönemde kentsel dönüşüm projeleri artık yasalaşmıştır. 1980'li yıllarda gündeme gelen 1990'lı yıllarda bazı belediyelerin bireysel olarak uyguladığ kentsel dönüşüm projeleri 2000'li yılların başında yasalaşarak bütün belediyelerin kentsel dönüşüm projelerini uygulamasının önü açılmıştır. Bu konudaki öncü ve en somut çalışma ise yine Ankara Büyükşehir Belediyesinin 5104 Sayılı Yasaya dayanarak yaptığı Kuzey Ankara Kentsel Dönüşüm Projesidir. 5104 Sayılı Yasanın hükümleri çerçevesinde yürütülen Kuzey Ankara kentsel dönüşüm projesiyle Esenboğa Protokol Yolu çevresinin düzenlemesini konu almıştır. Söz konusu projenin uygulanması için eksik olan hususlar 3194 Sayılı İmar Yasası ve 2985 Sayılı Toplu Konut Yasası'ndaki düzenlemeler çerçevesinde yürütülmüştür. Bu yasa sayesinde Altındağ ve Mamak’ta bulunan çok sayıda gecekondu ortadan kaldırılmış, gecekondular yerine TOKİ tarafından sosyal donatılı çok katlı modern binalar yapılmıştır. Bu uygulamadan sonra 2005 yılında çıkarılan 3593 Sayılı Belediye Yasasının 73. Maddesinde kentsel dönüşümle ilgili düzenleme yapılarak bütün belediyelerin kentsel dönüşüm projesi yapması ve uygulamasının önü açılmıştır. 


\subsection{Kentsel Dönüşümün Yasal Dayanakları}

Türkiye'de kentsel dönüşüm projelerinin yapılması, işlemleri, yürütülmesi ve uygulanması aşă̆ıdaki yasalara göre yapılmaktadır (Genç, 2008: 118):

2981 Sayılı İmar ve Gecekondu Mevzuatına Aykırı Yapılara Uygulanacak Bazı İşlemler ve 6785 Sayılı İmar Yasasının Bir Maddesinin Değiştirilmesi Hakkındaki Yasa. 5393 Sayılı Belediye Yasası (73. Maddedeki düzenleme ve yapılan değişiklikler). 5216 Sayılı Büyükşehir Belediyelerinin Yönetimi Hakkındaki Kanun Hükmünde Kararnamenin Değiştirilerek Kabulü Hakkındaki Yasa. 2985 Sayılı Toplu Konut Yasası. 6306 Sayılı Afet Riski Altındaki Alanların Dönüştürülmesi Hakkında Yasa. 6306 Sayılı Kentsel Dönüşüm Kanunu Uygulama Yönetmeliği, 5273 sayılı Arsa Ofisi Kanunu ve Toplu Konut Kanunu'nda ve Genel Kadro ve Usulü Hakkındaki Kanunun Eki Cetvellerin Toplu Konut İdaresi Başkanlığına Ait Bölümünde Değişiklik Yapılması Hakkında Yasa. 5226 Sayılı Kültür ve Tabiat Varlıklarını Koruma Yasası ve Çeşitli Kanunlarda Değişiklik Yapılması Hakkında Yasa. 5366 Sayılı Yıpranan Tarihi ve Kültürel Taşınmaz Varlıkların Yenilenerek Korunması ve Yaşatılarak Kullanılması Hakkında Yasa. 5104 Sayılı Kuzey Ankara Girişi Kentsel Dönüşüm Projesi Yasası. Bu alanda yapılan en son düzenleme 2018 Tarihli İmar Barışı (Yapı ruhsatı verme) Uygulamaları.

Kentsel dönüşüm projeleriyle dolaylı olarak ilgili olan ve bu alandaki son düzenleme olan İmar Barışının kentsel dönüşüm projelerinin uygulanmasına yardımcı olacağı ve önünü açacağı belirtilmektedir. Zira imar barışı her yapı için bir kayıt belgesi (tapu) vermeyi öngörmektedir. İmar Barışının 2. Madesinin ç) fıkrasında Yapı Kayıt Sistemini imar mevzuatına aykırı yapıların kaydedilmesi amacıyla oluşturulan elektronik yazılım sistemi olduğu belirtilmektedir. Ayrıca aynı düzenlemesinin 4. Maddesinin 5. Fıkrasında her yapı için bir Yapı Kayıt Belgesi düzenlenir ibaresi yer almaktadır. Bu düzenlemelerin gecekonduları ve kaçak yapıları kapsadığı açıktır. Bedeli ödenmek şartıyla bu yapıların hazine ya da belediyelere ait arsalarda yapılmış olması sonucu değ iştirmiyor. İmar Barışı, sınırlı istisnalar dışında bedeli ödenmek şartıyla hazine ya da belediyelere ait arsalarda yapılan yapılara da yapı kayıt belgesi verilebileceğine imkan tanımıştır. Böylece çok katlı gecekondular ve kaçak yapı sahiplerinin kentsel dönüşüm projeleriyle hak kaybına uğramayacakları belirtilmektedir. İmar Barışından önce gecekondu ve kaçak yapıların sahipleri tapusu olmadığı için hak kaybına uğrayacağı endişesiyle kentsel dönüşüm projelerindeyapısının yıkılmasına rıza göstermiyordu. Bu nedenle kentsel dönüşüm projeleri ya yıllarca sürüncemede kalıyordu ya da önemli bir ilerleme kayd edilmiyordu. Dolayısıyla imar barışı gecekondu ve kaçak yapı sahiplerinin hak kaybını önlediği için kentsel dönüşüm projelerinin daha kolay uygulanabileceği ve bu projelere ivme kazandıracağı belirtilmektedir.

Daha önce kentsel dönüşüm için tüm maliklerin muvafat vermesiyle yıkılabilen gecekondu ve benzeri yapılar son düzenleme ile çoğunluk yöntemine göre yıkılabileceği belirtilmektedir. Zira 10 Temuz 2019 Tarihli Resmi Gazetede yayımlanan 7181 Sayılı Tapu Kanunu ve Bazı Kanunlarda Değişiklik Yapılmasına Dair Kanunun 24. Maddesinde riskli yapıların yıkılması ve kentsel dönüşümün uygulanması bütün maliklerin değil 2/3çoğunluğun kararı yeterli görülmektedir (Resmi Gazete, 2019). Bu düzenleme bütün yapı sahiplerinin uzlaşmaya varmamaları nedeniyle uzayan kentsel dönüşüm projelerinin artık daha kısa sürede uygulanabileceğinin önünü açmıştır. 
Kentsel dönüşümle ilgili mevzuat kapsamında değerlendirilebilecek bir düzenlemede kalkınma planlarıdır. 2000'li yıllardan sonra hazırlanan kalkınma planlarında doğrudan ya da dolaylı olarak kentsel dönüşüm konusu ele alınmıştır. Bu alanda en son hazırlanan 11. Kalkınma planında kentsel dönüşüm konusu diğer kalkınma planlarına göre geniş olarak düzenlenmiştir. Söz konusu plana göre, kentsel dönüşümde katılımın esas alınacağı, riskli alanlardaki riskli yapıların muvafkat olmadan da yıkılacağı, bu kapsamda konutları yıkılanlara kira yardımının yapılacağı, yeni yapılacak konutların depreme dayanıklı olması gerektiği belirtilmiştir (Cumhur. Str. Baş. 2019: 175-177).

Türkiye'de kentsel dönüşüm projelerinin mevzuatı ve yasal dayanağı genel itibariyle yukarıda belirtilen yasalar ve düzenlemeler oluşturmaktadır.

\section{Kentsel Dönüşümün Türkiye'de Aktörleri}

Türkiye'de kentsel dönüşüm projelerinin uygulamaları merkezi yönetim, yerel yönetimler, mülk sahipleri ve özel sektör arasında varılan anlaşmalar kapsamında yapılmaktadır.

\subsection{Merkezi Yönetim}

Türkiye'de merkezi yönetim kentsel dönüşüm projelerine en çok TOKİ (Toplu Konut İdaresi Başkanlığı) aracılığıyla katılmaktadır. Ancak bazen kentsel dönüşüm projelerine kendi görev alanlarıyla ilgili bazı bakanlıkların da (Çevre ve Şehircilik Bakanlığı, Kültür ve Turizm Bakanlığı-tarihi eserlerin korunması- Tarım ve Orman Bakanlığı-tarımsal arazilerin korunması, 2B arazisi- gibi) katıldığg görülmektedir.

1980’li yıllarda kabul gören katılımcı yaklaşımla ile kentsel dönüşüm projelerine merkezi yönetim, yerel yönetimler, özel sektör de dahil olmuştur (Kalağan \& Çiftçi, 2012: 125). Ancak merkezi yönetimin yerel birimlere gereğinden fazla müdahale etmesi kentsel dönüşüm uygulamalarının aksamasına neden olabilir (Toprak, 2010: 15).

Ulusal düzeyde kentsel dönüşüm projelerinin başarılı olabilmesi için merkezi yönetimin belediyeler, özel sektör ve sivil toplum kuruluşlarına yönelik belli başlı bazı önlemlerialması gerekir. Söz konusu önlemler şöyle belirtilebilir:

Kentsel dönüşüm projelerine kredi sağlayan finans kuruluşlarına bazı ayrıcalıkların tanınması, yerel yönetimlerin kentsel dönüşüm projelerini geliştirmek için araç-gereç ve personel bakımından yeterli hale getirilmesi, kentsel dönüşüm projeleri konusunda deneyimli özel şirketlere öncelik verilmesi vekentsel dönüşüm projeleri geliştiren yerel birimlere iktisadi ve teknik destek sağlanması olarak belirtilebilir (Balamir, 2005: 28).

Merkezi yönetim büyük çaplı ve önemli kentsel dönüşüm projelerine finansal destek, teknik destek ve yasal kolaylık gibi yöntemlerle de katılabilmektedir. Örneğin Kuzey Ankara (Mamak) Kentsel Dönüşüm Projesine merkezi yönetimin Ankara Büyükşehir Belediyesine sağladığı yasal kolaylıkla (5104 Sayılı Yasa) katıldığı söylenebilir (Üstün, 2009: 3). 


\subsection{Yerel Yönetimler}

Yerel yönetim mevzuatı ve yasal düzenlemelerde il-ilçe belediyeleri ve büyükşehir belediyelerine kentsel dönüşüm için önem atfetmektedir (Kalağan \& Çiftçi, 2012: 127). Yerel yönetimlerin kentsel dönüşümle ilgili görev ve yetkilerini daha iyi görmek için 5393 Sayılı Belediye Yasası ve 5216 Sayılı Büyükşehir Belediye Yasasındaki düzenlemelere bakmakta fayda vardir.

5393 Sayılı Belediye Yasası'nda Kentsel Dönüşümün Yeri:5393 Sayılı Belediye Yasasının6. bölümü “Kentsel Dönüşüm ve Gelişim” başlığını taşımaktadır. İlgili bölüm içinde yasanın 73. Maddesinde "Belediye, belediye meclisi kararıyla; konut alanları, sanayi alanları, ticaret alanları, teknoloji parkları, kamu hizmeti alanları, rekreasyon alanları ve her türlü sosyal donatı alanları oluşturmak, eskiyen kent kısımlarını yeniden inşa ve restore etmek, kentin tarihi ve kültürel dokusunu korumak veya deprem riskine karşı tedbirler almak amaciyla kentsel dönüşüm ve gelişim projeleri uygulayabilir" (5393/73) düzenlemesi yer almaktadır. Dolayısıyla belediyeler yasadaki bu düzenlemeye dayanarak her türlü kentsel dönüşüm projesi yaparak uygulayabilir (Koçak \&Tolanlar, 2008: 405). 73. madde kapsamında kentsel dönüşüm uygulamalarına dâhil edilecek alanlar ve buralarda yapılacak faaliyetlerden bahs edildikten sonra maddenin 2. Fıkrasında, kentsel dönüşüm ve gelişim proje alanı olarak ilan edilecek alanların özelliklerine yer verilmektedir. Söz konusu madde kapsamında değinilen bu özellikler şunlardır:

- Alanın üstünde yapısı olan veya olmayan, imarlı veya imarsız bir alan mahiyetinde olmas1,

- Kentsel dönüşüm alanında mevcut veya yapılacak olan yapıların yükseklik ve yoğunluğunun belirlenmesi,

- Alanın büyüklüğüne dair hesaplamaların yapılması (bu büyüklük enaz 5 en fazla 500 hektar arasında bir büyüklük olmalıdır).

- Kentsel dönüşümün etaplar halinde gerçekleştirilebilmesi (bu konuların belediye meclisinin yetkisinde olduğu belirtilmiş) şeklinde sıralanmıştır (Yasin, 2006:15)

5393 Sayılı Belediye Yasasındaki düzenlemeden de anlaşıldığg gibi kentsel dönüşüm projelerinin yapılması ve uygulanması bakımından belediye meclisine yeterli yetki ve görev verilmiştir.

5216 Sayılı Büyükşehir Yasası'nda Kentsel Dönüşümün Yeri: 5216 Sayılı Büyükşehir Yasasının 3. bölümünde büyükşehir, ilçe ve ilk kademe belediyelerin görev ve sorumluluklarına değinilmektedir. Aynı başlıklı bölümün 7. Maddesinde, büyükşehir belediyelerinin görev ve sorumluluklarının dayanağı konusunda 5393 Sayılı Belediye Kanunu'nun 69. ve 73. maddelerine atıfta bulunmuştur. Ayrıca 5393 Sayılı Belediye Kanunu'nun ilgili maddesinde büyükşehir belediyelerinin görevleri ile ilgili teferruatlı olarak bilgi verilmiştir. Dolayısıyla her ne kadar 5216 Sayılı Büyükşehir Belediye Yasasında direkt olarak kentsel dönüşüm projeleriyle ilgili bir düzenleme yapılmamışsa da 5393 Sayılı Belediye Yasasındaki düzenlemeye dayanılarak kentsel dönüşüm projelerinin uygulanması konusunda Büyükşehir Belediyeleri önünde bir 
engel yoktur. Ayrıca Büyükşehir Belediyelerinin görev ve yetkileri belirtilirken 5393 Sayılı Belediye Yasasının 73. Maddesine atıfta bulunulması Büyükşehir Belediyelerinin kentsel dönüşüm projelerini yapmasının önünü açmaktadır. Bu nedenle büyükşehir belediyeleri kentsel dönüşüm konusunda yerel düzeyde öncü konumda görülmektedir.

\section{3. Özel Sektör ve Sivil Toplum Kuruluşları}

1980'li yıllarda liberal politikaların da etkisiyle kentsel dönüşüm projelerini sadece kamu sektörü tek başına yapmamakta, bu projelere yerel yönetimlerin yanı sıra artık özel sektöründe dahil edildiği görülmektedir. Özellikle büyük kentsel dönüşüm projelerin uygulanmasında özel sektörün, tecrübe, birikim ve ekipmanlarının önemli rol oynadığı görülmektedir. Bundan dolayı kentsel alanların dönüşümü, toplumsal gelişimi, ekonomik büyümesi, çevre koruması demokratik bir şekilde bütüncül bir yaklaşımla ele alındığg belirtilmektedir (Ataöv \& Osmay, 2007: 73).

Kentsel dönüşüm yerlerinde mekânsal alanların değişiminin yanında ayrıca değişik iktisadi sektörlerin işin içine çekilmesi ihtiyacı, sosyal çevrelerin geliştirilmesi, kolektif işlerin yapılması ihtiyacı özel sektörü de bu projelere ortak olmaya çekmiştir (Balamir, 2004: 8).

Avrupa Birliği'ne uyum sürecinde kentsel dönüşüm projeleri, Avrupa Birliği üyesi ülkelerde nasıl yapılıyorsa Türkiye'de de aynı şekilde yapılması gerekir. Günümüzde Avrupa Birliği üyesi ülkelerde kentsel dönüşüm projelerinde özel sektör önemli bir partner olarak kabul edilmektedir. Ayrıca iyi bir yönetişim, kentsel dönüşüm projelerinin uygulanması için önemli farkındalık oluşturabilir. Bu nedenle yönetimin yerel halkı ve piyasa mekanizmasını iyi anlaması gerekir. Yerel topluluğun kentle ilgili karar alma süreçlerinde yer almaları, doğacak kaynağın israfını engellemek, kentsel dönüşüm sürecin daha şeffaf hale getirmek, yönetim üzerinde kontrol sağlamak ve demokratikleşmesi bakımından önemlidir (Ataöv, 2005: 63).

Sivil toplum kuruluşlarından işin uzmanı ve mesleki kuruluşlardan Şehir Plancıları ve Mimarlar ve Mühendisler Odası da kentsel dönüşüm projelerine doğrudan ya da dolaylı olarak katılmaktadır. Sivil Toplum Kuruluşları, kentsel dönüşüm projeleri konusunda yayınladıkları raporlar ya da yaptıkları bilimsel çalışmalarla ya bu projelere destek olmakta ya da eleştirerek bu projelerin kent halkının lehine olması için yol göstermektedir. Mesleki Sivil Toplum Kuruluşları bazen de kamu kurumlarının fark edemediği ama onların fark ettiği kentlerin belli bölgelerinin kentsel dönüşüme dahil edilmesi gerektiği konusunda öncü raporlar yayınlayarak karar alıcılara bu konuda politika oluşturması konusunda yol göstermektedir. Özellikle 1999 yılında meydana gelen Marmara depreminden sonra Mimarlar ve Mühendisler Odası ve Şehir Plancıları Odasının depreme dayanıklı konutların yapılması konusundaki bilimsel çalışmaları kentsel dönüşüm projelerinin geliştirilmesi ve yaygınlaştırılması konusunda politikanın oluşturulmasında etkili olmuştur. Bu kapsamda Türkiye Mimarlar Mühendisler Odası Birliği kentsel dönüşümün ilkeleri olarak bazı maddeleri yayınlamıştır (TMMOB, 2013). Ancak Türkiye'de Sivil Toplum Kuruluşların henüz Kentsel Dönüşüm Kararlarını alma ya da bu kararlara katılma yetkisinin olmadığını da belirtmek gerekir. 


\section{Diyarbakır Sur Kentsel Dönüşüm Uygulamaları}

Diyarbakır Sur ilçesi kentsel dönüşüm uygulamaları anlatılmadan önce ilçe hakkında genel bilgi edinmek amacıyla konumu, tarihsel geçmişi, yapılaşması ve imar durumu hakkında kısa bilgiler vermekte fayda vardır. Bu nedenle önce bu konular hakkında kısa bilgiler verildikten sonra Suriçi kentsel dönüşüm uygulamaları anlatılmıştır.

\subsection{Sur İlçesinin Konumu ve Tarihsel Geçmişi}

Sur İlçesi adını Diyarbakır'ın tarihi ve antik surlarından almaktadır. Geleneksel ve sivil mimarlık örneklerinin çok fazla içinde yer aldığı Sur İlçesi, geleneksel, dar ve organik sokak dokusu tarihsel süreçteki bütün müdahalelere rağmen çok fazla bozulmadan günümüze kadar gelebilmiştir (Yıldırım, 2012: 239).

Diyarbakır İli Sur İlçesinin tarihi geçmişi M.Ö. 7250-7000'li yıllara dayandığı ifade edilmektedir (Çiçek, 2007: 29). Kent dokusunu önemli ölçüde biçimlendiren Diyarbakır Surlarının M.Ö. 2000'li yıllarda kentte hakim olan Hurrilerdöneminde yapıldı ğı, Konstantinus Döneminde ise (330-377) 330'lu yıllarda bugünkü sınırlarına ulaşacak şekilde genişletildiği belirtilmektedir (Karakaş vd., 2016: 369). Diyarbakır, Mittani, Asur, Urartu, Pers, Roma ve Bizanslıların egemenliğinden sonra 639 yılında Müslüman Araplar tarafından fethedilmiş, 1515 yılından itibaren ise Osmanlı Devletinin yönetimine girmiştir (Nabikoğlu \& Dalkılıç, 2013: 26). Tarihi, kültürel ve mimari bakımdan bütün bu uygarlıkların eser ve izlerinin önemli kısmı Suriçi Bölgesi'nde bulunmakta, bu nedenle Sur ilçesi bir açık hava müzesi olarak kabul edilmektedir (Bağlı \& Binici, 2005: 104).

\subsection{Sur İlçesinde Yapılaşma ve İmar Durumu}

Mevcut bilgilere göre Diyarbakır İlinin ilk imar planı 1937 yılında yapılmıştır. Bu plan uzun bir süre uygulandıktan sonra 1962 yılında Suriçi Bölgesi, 1965 yılındaSurdışını kapsayan imar planları yapılmıştır. Ayrıca kentin geneli için 1983 ile 1985 yılları arasında hazırlanan imar planı 1993 yılında revize edilmiştir. 1990'lı yıllarda ilçe olan Kayapınar'ın İmar Planı 2001 yılında yürürlüğe konulmuştur. Yine 2006 yılında Diyarbakır genelinde uygulanan 1/25.000 ölçekli Diyarbakır Büyükşehir Nazım İmar Planı hazırlanmıştır (Karaaslan, 2018: 340).

Suriçinde, toplam 18 mahalle bulunmakta, bunların 16'sı Sur İlçesine, kalan 2'si Yenişehir İlçesine bağlıdır (Diy. Büyükşehir Bele. 2011). Bu mahallelerde 2015 yılındanki terör ve güvenlik olaylarından önce toplam 8935 yapı bulunmaktaydı (Karaaslan, 2018: 344).2015 yılının sonlarında başlayan ve 2016 yılının Mart-Nisan aylarında biten terör/güvenlik olayları neticesinde bu yapı stoğunda ciddi azalmalar meydana geldi. Bu yapıların 2851'i tek katlı, 4660'ı iki katlı, 722'si üç katlı, 310'u dört katlı, 272'si beş katlı, 168'i altı katlı, 78'i yedi katlı, 16'sı sekiz katlı ve 7'si dokuz katlıdır. Bu yapıların \% 70,6'sı yığma, \% 29,4 ise karkastır (Karakaş vd., 2016: 373).

Surların yüksekliğinin 10-12 metre arasında olduğu gözönünde bulundurulduğunda dikey yapılaşmanın tarihi dokuyu ne oranda tahrip etmiş olduğu ortaya çıkmaktadır (Nabikoğlu\& Dalkılıç, 2013: 30). Her katın ortalama yüksekliği 3 metre olduğu varsayıldığında 3 katın üstündeki bütün yapıların tarihi dokuyu tahrip ettiği görülmektedir (Çatalbaş, 2012: 55). Bu 
yapılar aynı zamanda ruhsatsız veya ruhsata aykırılıklar sebebiyle yatay düzlemde de çarpık yapılaşmaya örnek oluşturmaktadır. Sur içindeki yapılardan 3 kat ve altındaki yapıların önemli bir kısmı ruhsatsız yapılardır ve bunlar yatay düzlemde çarpık yapılaşmayı oluşturmaktadır. Zira Sur Belediyesi verilerine göre Suriçi Bölgesindeki tescilli yapı sayısı; anıtsal yapı 149, sivil mimari yapı ise 465 yani toplam 614'tür. Çevre ve Şehircilik Bakanlığı verilerine göre ise tescilli yapı sayısı toplam 907'dir (Karaaslan, 2018: 344).

Her iki (Sur Belediyesi ve Çevre ve Şehircilik Bakanlığı) veri de baz alındığında tescilli yapı oranıilçedeki toplam yapının \%10'nu geçmemektedir. Bu veriler mevcut yapılaşmanın tehlikesini ve zararlarınıgözlerönüne sermeye ve kentsel dönüşüme olan ihtiyacı göstermeye yetmektedir.

\subsection{Sur İlçesi (Suriçi) Kentsel Dönüşüim Uygulamaları}

Suriçi Bölgesi kentsel dönüşüm projesi Diyarbakır'ın ilk kentsel dönüşüm uygulamasıdır. Bu projeyi Türkiye' deki diğer kentsel dönüşüm projelerinden ayıran temel özellik bu projenin tarihi ve kültürel doku üzerinde, özellikle kentsel sit alanında gerçekleştiriliyor olmasıdır (Karaaslan, 2018: 340). Ayrıca tarihi Surların devamı ve müştemilatı olarak kabul edilen Havzel Bahçelerinin UNESCO tarafından dünya kültür mirasına alındığını belirtmek gerekir (Dağtekin, 2018: 852).

Diyarbakır Sur İlçesi kentsel dönüşüm projesi ile hem kentte sivil mimariye ait eskiyen ve yıkılma tehlikesi olan yapıların yenilenmesi hem de kentin tarihi ve kültürel yapısının korunması hedeflenmektedir. Kentsel dönüşüm kavramı tarihte ilk kez Batı Avrupa'da Sanayi Devrimi'nden sonra zor şartlarda yaşayan işçi sınıfının içinde bulunduğu kötüşartların dayatmasıyla ortaya çıkmıştır (Üstün, 2009: 14). Dolayısıyla Türkiye'de yeni olsa da Batı Avrupa ülkeleri ve Kuzey Amerika'da kentsel dönüşümün izleri 19. yüzyıla kadar geri gitmektedir (Aktay vd., 2012: 3). Ülkemizde 1980'li yıllardan itibaren uygulamaya çalışılan kentsel dönüşüm projelerinin (Ayhan, 2013: 85) gelişimine paralel olarak Diyarbakır Surların içindeki kentsel bozulmaya bağlı olarak burada da kentsel dönüşüm projelerinin uygulanmasına ihtiyaç duyulmuştur.

Diyarbakır'ın merkez ilçelerinden Sur, nüfus ve alan bakımından diğer ilçelerden küçük olmasına rağmen sahip olduğu tarihi, antik, dini, kültürel ve turistik değerler bakımından Diyarbakır metropol alanın en önemli ilçesidir. 1980'li yılların sonundan itibaren ekonomik ve güvenlik nedenleriyle kırsal alandan kentte gelen göçlerle Sur ilçesinin nüfusu kısa sürede katlanarak artmıştır (Karacadağ Kal. Ajansı \&Diy. Büyükşehir Bel., 2013: 18). Kırsal alandan gelen yoksul ve dar gelirli aileler surların içinde ve surlara bitişik gecekondular ve kaçak konutlar yapmıştır. Bu şekilde gelişen çarpık ve kaçak yapılaşma tarihi surlara ve surların müştemilatı olan burçlara zarar vermiştir (Çatalbaş, 2012: 49-50). Sur içinde yaklaşık 9.000 civarında yapı bulunmasına rağmen imarlı ve tescilli olan yapıların sayısı en iyimser tahminle (Sur Belediyesi verilerine göre 614, Çevre ve Şehircilik Bakanlığı verilerine göre 907) 1.000'ni yani \% 10'nu geçmemektedir. Dolayısıyla sur içindeki hem tarihsel yapıları ve dokuyu korumak hem de Diyarbakır'ın en eski yerleşim yeri olan bu bölgedeki tarihi sivil mimarlık eserleri koruyarak çağdaş bir yapıya kavuşturmak için kentsel dönüşüm bir ihtiyaç olmuştur (Çatalbaş, 2012:53). 
Tarihsel süreçte Diyarbakır'a egemen olan Mittani, Asur, Urartu, Pers, Roma, Bizanslılar ve Osmanlı Devletinin izi ve birçok tarihsel eseri Sur ilçesinin sınırları içinde yer almaktadır. Bu tarihi dokunun korunabilmesi için 6306 Sayılı Afet Riski Altındaki Alanların Dönüştürülmesi Hakkında Yasa kapsamında Suriçi bölgesi, Diyarbakır Kültür ve Tabiat Varlıklarını Koruma Bölge Kurulunca 29.9.1988 Tarih ve 38 Sayılı Kararıla "Kentsel Sit Alanı" olarak ilan edilmiştir (Çatalbaş, 2012: 50). Suriçi Bölgesi, kentsel sit alanı olarak toplamda 187 hektar ve 16 mahalleden oluşmaktadır. Sur İlçesi Kentsel Dönüşüm Projesi çerçevesinde riskli yapılar ve riskli alanlarla ilgili çalışmalar kapsamında Suriçi bölgesinde bulunan 187 hektar riskli alan içerisinde yaklaşık 8900 yapı, 14763 Hane ve 4887 işyeri bulunduğu belirtilmektedir (Hürriyet, 2019). Diyarbakır Kültür ve Tabiat Varlıklarını Koruma Bölge Kurulunun "Kentsel Sit Alanı” kararı ile Surların dibinden itibaren 50 metre genişlikteki şerit, "Surların Koruma Bandı" olarak belirlenmiştir (Karaaslan, 2018: 340).

Herhangi bir yer sit alanı olarak ilan edildiğinde diğer bütün planlar durmakta, söz konusu sit alanı için koruma planları yapılmaktadır. Suriçi bölgesine ait ilk Koruma Amaçlı İmar Planı, 1990 yılında hazırlanmış ve bu plan 09.11.1990 tarih ve 609 sayılı kararla Kültür ve Tabiat Varlıklarını Koruma Bölge Kurulu tarafından onaylanmıştır (Diyarbakır Büyükşehir Belediyesi, 2012:11). Ama söz konusu bu plan, Suriçi'nin yapısal sorunlarını çözememiş ve ilçede çarpık yapılaşma devam etmiştir. 1980'li yılların sonu ve 1990'lı yılların başında ekonomik ve güvenlik kaygılarıyla kentte gelen göçlerle Diyarbakır merkezin nüfusu kısa sürede çok artmıştır. 1990-2000 arası dönemde, Türkiye'de kentsel nüfus \%o 18,3 oranında artarken, Diyarbakır' ın kentsel nüfusu \%o 37,8 artış göstererek neredeyse Türkiye'nin iki katı artış hızına ulaşmıştır (Çatalbaş, 2012: 48). Bu artıştan en çok Sur ilçesi etkilenmiş, ilçenin nüfusu kısa sürede katlanarak artmıştır. Bu gelişmeler neticesinde başta surların içi olmak üzere yakın çevresiyle birlikte Sur ilçesi imarsız, plansız, düzensiz kaçak yapılar ve gecekondularla dolmuştur. Bu yapılaşmanın bir kısmı surlara ve burçlara bitişik konumda gerçekleşerek, tarihi surlara ve burçlara zarar verecek boyutlara ulaşmıştır (Kejanlı \& Dinçer, 2011: 101).

Bu tür gelişmelerden (gecekondu ve kaçak yapılaşma) dolayı Sur ilçesinin bozulan tarihi dokusu ve mimari yapısının önüne geçmek ve kenti eski durumuna kavuşturmak için kentsel dönüşüm projesi uygulamak ihtiyaç durumuna gelmiştir. Yaşanan göçlerin de etkisiyle bozulan kentsel yapılaşmanın önüne geçmek amacıyla, TOKİ Başkanlığı ve Diyarbakır Büyükşehir Belediyesi arasında 31.03.2008 tarihinde "Diyarbakır Alipaşa ve Lalebey Mahallesi Kentsel Dönüşüm Projesine İlişkin Protokol"imzalandıktan sonra Suriçi kentsel dönüşüm projesine başlanmıştır (Mimarlık Dergisi, 2019). Suriçi Bölgesi'ndeki kentsel dönüşüm projesinin amacı, “Diyarbakır'ın aldığı yoğun göç karsısında tahrip olmuş, bozulmuş, yoğun olarak yıpranmış Tarihi Sur Koruma Bandı ve Suriçi'nin tarihi dokuya uymayan gecekondu ve/veya kaçak yapılardan arındırılarak, yüzyıllar boyu medeniyetlere ev sahipliği yapmış Diyarbakır İline yakışır şekilde tarihi dokunun yeniden kente kazandırılması" olarak belirtilmişstir (Çatalbaş, 2012: 51).

2008 yılında 5393 Sayılı Belediye kanunu, 6306 Sayılı Afet Riski Altındaki Yerlerin Düzenlenmesine İlişkin Kanun ve 2985 Sayılı Toplu Konut Kanunu çerçevesinde TOKİ ve Diyarbakır Büyükşehir Belediyesi arasında imzalanan protokolün ardından Sur ilçesinde gecekonduların yoğun olarak bulunduğu dört mahalle (Cevatpaşa-Fatihpaşa ve Alipaşa-Lalebey) kentsel dönüşüm kapsamına alınmıştır. Söz konusu bu mahallelerde oturanlardan anlaşmayı 
kabul edenlerden bazıları Kayapınar İlçesinin Çölgüzeli Mahallesindeki TOKİ konutlarına taşınmıştır. Diyarbakır Suriçi Kentsel Dönüşüm projesi kapsamında yapılacak çalışmayla riskli yapılar tespit edilerek yıkım işlerine başlanacağı belirtilmiştir. Bu çerçevede proje kapsamına giren mahallelerdeki riskil yapılar olan gecekondular ile harabe hâlindeki yapılar yıkılmıştır. Cevatpaşa-Fatihpaşa Mahallelerinden 231 mülk sahibi ve 63 kiracıya, Alipaşa-Lalebey Mahallelerinde ise 287 mülk sahibi ve 144 kiracıya çekilen kura sonucu Çölgüzeli'ndeki TOKİ konutları tahsis edilmiştir (Politeknik, 2019). Ancak bu kentsel dönüşüm projesi belli bir süre uygulandıktan sonra bazı mülk sahiplerinin uzlaşmaya varmaması üzerine durdurulmuş ve bu konuda önemli bir mesafe alınamamıştır.

2008 yılında Sur ilçesinde kentsel dönüşüm uygulamaları başlamasına rağmen Alipaşa ve Lalebey Mahallerinde ikamet edenlerden bazıları TOKİ'nin anlaşma teklifini reddetmiş ve evlerini terk etmemiştir. Bazı mülk sahiplerinin kentsel dönüşüm ve yıkıma karşı çıkışların ardından TOKİ'nin bu mahallelerdeki yıkım sürecini tamamlayamadığı ve Sur İlçesinde (Suriçi Bölgesi) başlattığı kentsel dönüşüm uygulamalarını 2012 yılında durdurmak zorunda kaldığ belirtilmiştir (Aslan vd., 2016: 8). Kensel dönüşüm projesinin uygulamasının durdurulmasında vatandaşların TOKİ uygulamalarından duydukları rahatsızlığı da belirtmek gerekir. Bu kapsamda Suriçibölgesinde kentsel dönüşümle ilgili yapılan bir ampirik çalışmadadeneklerin \% 82'nin TOKI'nin kentsel dönüşüm uygulamalarından memnun olmadıkları belirtilmiştir (Aslan, vd., 2016: 14-16).

2008 yılında başlanan 2012 yılında durdurulan kentsel dönüşüm projesi kapsamında bu sureçteSuriçi Bölgesindeşu faaliyetler de gerçekleştirilecekti. Suriçi kentsel dönüşüm protokolüne göre Suriçi’ndeki kamulaştırma ve yıkım işlemleri Büyükşehir Belediyesi tarafından yürütülecek, TOKİ, Çöl güzeli mevkiinde, 2 etap halinde toplam 1272 konut inşa edecekti. 2009 yılında imzalanan son protokolün ardından Sur'da yıkım işlemleri başlamıştı, fakat özellikle Alipaşa, Lalebey Mahallelerinde yaşayan vatandaşların TOKI'nin anlaşma teklifini reddetmesi ve tasfiyeye karşı direnmesi üzerine proje yarıda kaldı (Mimarlık Dergisi, 2019).

Suriçi kentsel dönüşüm projesi uygulaması istenilmeyen bazı nedenlerden dolayı durdurulmuşsa da surların içindeki yapıların bozulan durumu ve tarihsel mirasın korunması gereği yetkililerin dikkatini çekmeye devam etmiştir. Bu kapsamda Diyarbakır Büyükşehir Belediyesi Çevre ve Şehircilik Bakanlığıyla ortak çalışma isteğinde bulunmuştur. Kentsel Dönüşüm Projesi kapsamında Diyarbakır Büyükşehir Belediyesi ile TOKİ arasında yapılan 2008 tarihli protokole istinaden; Diyarbakır İli, Sur İlçesi, tarihi Sur Koruma sınırları içerisinde yer alan Alipaşa-Lalebey ve Cevatpaşa-Fatihpaşa Mahallerinde bulunan gecekondu kentsel dönüşüm proje alanı olarak belirlenen alanların Büyükşehir Belediyesinin istemi üzerine Bakanlar Kurulu'nun 14.01.2013 Tarih ve 2013/4215 Sayılı Kararıyla acele kamulaştırılması yoluna gidilmiştir (Resmi Gazete, 2012). Diyarbakır Büyükşehir Belediyesi'nin 15.10.2012 Tarih ve 5414 Sayılı Kararı ileÇevre ve Şehircilik Bakanlığı'na göndermiş olduğu yazıda; "Suriçi Bölgesinde 2 katın üstündeki yapıların fiziki ve ekonomik ömrünü tamamladığı ve mevcut durumun can ve mal kaybına sebebiyet verme riski taşıdı̆̆ı" tespit ve değerlendirmeleri ile birlikte "Suriçi Bölgesinde bulunan yüksek yapılarla ilgili olarak Bakanlıkla ortak çalışma yapılması" isteğinde bulunmuştur. Bu istek üzerine Çevre ve Şehircilik Bakanlığı ise 15.10.2012 Tarih ve 1546 Sayılı Yazıyla Suriçi Bölgesinde bulunan 187 hektarlık alanın riskli alan ilan 
edilmesini Bakanlar Kurulu'ndan istemiş, Bakanlar Kurulu da 22.10.2012 Tarih ve 2012/3900 Sayılı Kararı ile mezkûr alanı riskli alan ilan etmiştir (Karaaslan, 2018: 341). Kentsel dönüşüm projesi kapsamında riskli yapılar, riskli alanlar ve rezerv alanlar ayrı ayrı şöyle belirlenmiştir (Diy. Valiliği Çevre ve Şehircilik Bak. 2019).

Riskli Yapılar: Riskli alanda, ilk etapta ilan edilen riskli yapı sayısı 49, riskli hane sayısı 564, ama yıkılan yapı sayısı 12, yıkılan hane sayısı 128'dir. Diğer riskli yapılar ise mülk sahipleri rıza gösmediği için yıkılmamıştır.

Riskli Alanlar: Sur İlçesinde, Suriçi Bölgesi sınırları içinde kalan yaklaşık 187 hektarlık alan, riskli alan ilan edilmiştir. Çalışma kapsamında bu riskli alanda aşağıdaki faaliyetler gerçekleştirilmiştir( Hürriyet, 2019).

1. Etapta, Suriçi Bölgesi’ndeki riskli yapılardan 33 taşınmazın tamamı kamulaştırılmış ve yıkımı tamamlanmıştır.

2. Etapta, kamulaştırma işlemleri kapsamında 15 bina ve 43 malikle anlaşılmıştır. Toplam tahmini kamulaştırma bedeli 5 Milyon TL'dir.

3. Etapta, Celal Güzelses Yeraltı çarşısında bulunan 89 işyeri sahibiyle kamulaştırılma için görüşülmüş ve belli oranda uzlaşma sağlanmıştır. Kamulaştırma bedeli yaklaşık 3.5 Milyon TL'dir.

4. Etapta, Ulucami ve Zinciriye Medresesi çevresinde 25 bina ve toplam 130 mülk sahibiyle görüşülerek kamulaştırılma çalışmaları sürdürülmüştür. Kamulaştırma bedeli yaklaşık 5 Milyon TL'dir. Toplam 4 etaptaki projeden beklenti, Ulu Cami etrafının sağlıklaştırılması, Suriçi Bölgesinde örnek bir alan oluşturulması ve kentsel dönüşüm faaliyetlerinin bu kapsamda devam ettirilmesidir. Tahmini proje maliyeti 14-15 Milyon TL, etkilenen nüfusun 400 ile 500 kişi olacağı öngörülmüştür (Çatalbaş, 2012: 48).

Rezerv Alanlar:Sur ilçesinde Dicle Vadisi ve çevresi (Hevsel Bahçelerinin bazı kısımlarıdahil) kentsel dönüşüm projesi kapsamında 1080 hektarlık alan, rezerv alan ilan edilmiştir. Ancak planlanan bu rezev alanlar kentsel dönüşüm için yeterli bulunmamakta Diyarbakır'daki merkez ilçelerde kentsel dönüşüm ihtiyacını karşılayabilmek için en az 3000 hektarlık rezerv alana ihtiyaç olduğu belirtilmektedir.

\subsection{Sur İlçesi Kentsel Uygulamalarında Son Durum}

2015 yılının sonlarında başlayan ve 2016 yılının Mart ayında biten güvenlik/terör olayları neticesinde surların içindeki birçok ev, işyeri, tarihi ve turistik yerler kullanılamayacak derecede tahrip olmuş, Sur ilçesinin birçok yeri adeta harabeye dönmüştür (Sami, 2017: 392). 2015 yılında yaşanan çatışmalar sebebiyle 675 adet binanın tamamen yıkıldı ̆̆ 1,823 binanın ağır hasar gördüğ̈̈i, 714 binanın az hasar gördüğü, 597 adet korunmaya değer yapının da hasar gördüğü, toplamda 2809 yapının hasar gördüğü Bakanlık tarafından ifade edilmiştir (Karaaslan, 2018: 45). Kısaca bu olaylarda Sur ilçesinde bulunan 6 mahalle tamamen çöküntü altında kalmıştır. Bu mahallelerde yaşayan insanlar için Sur bölgesinde halkın sorunlarının çözümüne ilişkin Çevre ve Şehircilik Bakanlığının bünyesinde irtibat büroları kurularak, paneller yapılmış, seminerler düzenlenmiştir. Bu gelişmeler çerçevesinde 25 Mart 2016 tarihli Resmi 
Gazete'de, 2016/8659 Sayılı Bakanlar Kurulu kararı ile yeniden kentsel dönüşümün yasal zemini duyuruldu. Buna göre sürecin, 21 Mart 2016' da Çevre ve Şehircilik Bakanlığı tarafından alınan "acele kamulaştırma" kararı çerçevesinde işlendiği söylenmektedir (Eşin, 2018: 16). Bu proje kapsamında 80'den fazla birimin kamulaştırıldığ 1 50'den fazla birimin yıkımının gerçekleştirildiği ve 100 birimin de kamulaştırma işlemlerinin pazarlık aşamasına getirildiğ $i$ belirtilmektedir (Çevre ve Şehircilik Bakanlığı, 2015: 54). 2015 yılının sonunda başlayan 2016 yılının Mart ayında biten güvenlik/terör olaylarından dolayı Suriçinin bazı semtleri içinde yaşanılamayacak derece zarar görmüş olması, ayrıca kaçak yapılar, gecekondular, plansız, düzensiz yapılaşma sonucu ilçesinin bozulan tarihi, turistik, dini veantik yapıların yeniden onarılması ve yaşanılabilir hale getirilmesi için Suriçi Bölgesinin tamamını kapsayan kentsel dönüşüme ihtiyaç duyulmuştur. Bu tür nedenlerle kentsel dönüşüm adına alınan karar konu itibariyle yerinde ve doğru bir karardır. Ancak ayrı bir tartışma konusu olan acele kamulaştırma işleminin hukuka uygunluğu konusu bu çalışmada tartışılmayacaktır.

Güvenlik/terör olaylarından dolayı Sur ilçesinde mağdur olan ailelere yönelik 1500 konutun yapıldığg belirtilmiştir. Yetkililer Diyarbakır Sur İlçesi Kentsel Dönüşüm Projesi uygulamasında vatandaşlara metrekareye karşılık konut verildiğini belirtmektedir. Örneğin; Surların içinde 100 metrekare konutu olan bir vatandaş, istediği TOKİ konutu da 100 metrekare ise herhangi bir borçlanma olmadan konut sahip olabilecektir. Dolayısıyla 100 metrekare karşılığında 100 metrekarelik konut verileceği belirtilmektedir. Vatandaşın daha önceki konutu niteliksiz, dayanıksız ve riskli olabilir. Ama kentsel dönüşüm sonrası hak sahibi vatandaşlara sıfır bir konut teslim edilmektedir. Bunun için vatandaşın borçlanmasına da gerek yoktur. Eğer vatandaşın kentsel dönüşümden önce 100 metrekare konutu varsa ve TOKİnin yaptırdığı konutlardan 120 metrekarelik konut talep ediyorsa, sadece 20 metrekarelik için borçlanma yapılacak. Dolayısıyla kentsel dönüşüm projesi kapsamında her bir hak sahibine bir konut verme imkanı olduğu belirtilmektedir. Örneğin hak sahibi bir vatandaşın 3 katlı konutu/binası varsa bu amaçla yaplan konutlardan 3 konut verileceği belirtilmektedir (Hürriyet, 2019).

Diyarbakır Sur İlçesi Kentsel Dönüşüm Projesi uygulaması kapsamında Suriçindeki Alipaşa-Lalebey ve Cevatpaşa-Fatihpaşa Mahallerinde yapılan çalışmalar ile bu mahalleler gecekondulardan temizlenerek, sur çevresindeki iki mahallede yer alan çoğu gecekondu 1596 konutun yıkılmasından sonra ortaya çıkacak alanın; kent park, yeşil alan ve şehrin diğer ihtiyaçları doğrultusunda değerlendirilmesi planlanmıştır (Çatalbaş, 2012: 51).

2016 yılında yeniden (ikinci kez) uygulanmaya konulan Diyarbakır Sur İlçesi Kentsel Dönüşüm Projesi kapsamında TOKİ tarafından Üçkuyular ve Çölgüzeli bölgesinde hak sahiplerine konut yapılmaktadır. Bu konutlardan 795 tanesi tamamlanmış ve hak sahiplerine kura ile teslim edilmiştir. Geri kalanların yapımının sürdügü belirtilmektedir. Proje kapsamında hak sahipleri için konutları sadece TOKİ yapmamakta aynı zamanda Çevre ve Şehircilik Bakanlığı da toplu konut yapmaktadır. Çevre ve Şehircilik Bakanlığı olayların yaşandığı Sur ilçesi'nin 6 mahallesinde konut yapımları sürmektedir. Olayların yaşandığı bölgede yukarıda da belirtildiği gibi 1500 konut yapılacağı belirtilmektedir. Bu konutlar, Diyarbakır'ın mimarisine özgü şekilde, bazalt taşlarıyla inşa edilmektedir. İsteyen hak sahiplerine bu konutlardan da verileceği belirtilmektedir. Bu konutlar için şu ana kadar 500 kişinin başvuruda bulunduğu belirtilmektedir. Ayrıca olaylar esnasında zarar gören 1300 hak sahibine ödeme yapıldığı belirtilmektedir (Emlakta son dakika, 2019). 
TOKİ tarafından Diyarbakır'ın Üçkuyular ve Çölgüzeli semtlerinde kentsel dönüşüm kapsamında yapılan konutlar için vatandaşlara üç seçenek sunulduğu belirtilmektedir (Hürriyet, 2019).

1- Evinin arsasında yeni inşa edilecek konutu.

2- TOKİ'nin inşa ettiği/edeceği konutlardan biri.

3- Hak sahiplerine evlerinin karşılı̆̆ında verilecek ücret.

Halk kendi seçimine bağlı kalarak bunlardan birini tercih edebilecektir. Tabi bunun yanında zarar gören tescilli ev, cami, kilise gibi kamusal yapılar içinde ayrı bir değerlendirme söz konusu olmuştur. Bu tür yapılar devlet tarafından karşılıksız bir şekilde onarılarakaslına uygun hale getirildikten sonra hizmete sunulacaktır.

2016 yılında Bakanlar Kurulu tarafından acele kamulaştırma kararı alındıktan ve kamulaştırma işlemleri tamamlandıktan sonra koruma amaçlı imar planına uygun olarak inşa süreci başlamıştır (Eşin, 2018:17). Bakanlık bu inşa sürecini 60 ayda ve aşama aşama yerine getireceğini mahkemelere (bazı mülk sahipleri acele kamulaştırma kararına karşı Çevre ve Şehircilik Bakanlığına dava açmıştır) gönderdiği savunmalarda belirtmektedir. Ancak bütün bu inşa faaliyetinin merkezi bütçe bakımından çok büyük bir mali yükün olacağıve bu mali yükün ülkenin içinde bulunduğu ekonomik koşullar gözönündebulundurulduğundabelirtilen sürede bitmesinin mümkün gözükmediği ifade edilmektedir. Bütün olumsuzluklara rağmen 2016 yılında acele kamulaştırma (Eşin, 2018: 16) kapsamında başlanan kentsel dönüşüm uygulamaları kapsamında orijinal yapısıyla uyumlu olmasa da Melik Ahmet Caddesi üzerinde bulunan işyerlerinin dış cephelerinin yenilendiği, binaların boyandığı, Hazreti Süleyman Camii ve İçkale bölgelerinin çevre düzenlemelerinin tamamlandığ 1 , Ali Paşa Mahallesinde geleneksel Diyarbakır evleri ve mimarisini tam olarak yansıtmasa da müstakil evlerin inşasına başlandığı, bazı tarihi yapılarla ilgili restorasyon süreci başlatıldığı görülmektedir. Ancak yine belirtmek gerekirki inşa sürecinin 60 aylık periyotta bitmesi mümkün gözükmemektedir (Karaaslan, 2018: 369).

2016 yılında başlanan kentsel dönüşüm uygulamaları kapsamında yeni yapılan evlerin surların boyunu aşmayacağı belirtilmektedir. Kentsel dönüşüm kapsamında ilk etapda yapılan 293 konutun 2019 yılında hak sahiplerine verileceği belirtilmektedir (Haber Türk, 2019).

Bütün olumsuzluk ve aksaklıklara rağmen Diyarbakır İli Sur İlçesi Kentsel Dönüşüm Projesinin uygulanmaya başladığı, bu kentsel dönşüm projesiyle sadece konut yapılmadı̆̆ aynı zamanda Diyarbakır'ın tarihi, kültür ve inanç turizmiyle bir destinasyon merkezi haline getirilmeye çalışıldı $\breve{g}_{1}$ ifade belirtilebilir.

\section{Sonuç}

Kentsel dönüşüm projeleri genelde kentlerin zamanla yıpranan, yıkılan ve kullanılamaz hale gelen gecekondu ve kaçak yapıların yıkılması, yerine çağdaş ve yaşanılabilir yapıların yapılması amacıyla uygulanmaktadır. Kentlerin fiziki yapısıyla sosyal sorunları arasında direkt bir ilişkinin kurulması, kentlerdeki önemli sorunların başında gelen gecekondu ve kaçak yapılaşmanın engellenmesi, var olanların ortadan kaldırılarak yerine sosyal donatılarıyla 
çağdaş yapıların yapılması kentsel dönüşümün başka bir amacı olarak belirtilebilir. Günümüzde kentsel dönüşüm projeleri sadece gecekondu, eski ve yaşanılamaz konut alanlarını yenilemesi amacıyla değil aynı zamanda kentlerdeki fiziki ve sosyal alanları tehdit eden çöküntü alanlarının yeniden canlandırılması ve iktisadi hareketliliği getirecek stratejileri geliştirerek kentsel refah ve yaşam kalitesini artırmak amacıyla da yapılmaktadır. Kentsel alanların etkin bir şekilde kullanılması, kentlerin gereksiz yere geniş alana yayılmasının önlenmesi, düşük ve orta gelirli kent sakinlerinin konut edinme stratejilerinin geliştirilmesi kentsel dönüşümün amaçları olarak belirtilebilir.

Batı Avrupa'da Sanayi Devrimiyle birlikte insanlar kentlere göç etmiş, sanayi kuruluşlarında iş buldukları için sanayi bölgelerine yakın ama alt yapısı olmayan yerlerde, sınırlı imkanlarıyla gecekondulara benzer derme çatma konutlar yaparak buralarda yaşamaya başlamıştır. İşçi ve yoksulların içinde yaşadığı bu slum (yoksulluk) yuvalarını ortadan kaldırmak ve kentleri daha düzgün konut ve yapılara kavuşturmak isteği batılı düşünürleri ve yöneticileri düşündürmüş, belli bir fikir jimnastiğinden sonra kentsel dönüşüm projeleri kent planlarında yer almaya başlamıştır. Birinci ve İkinci Dünya Savaşları'nda yakılan ve yıkılan kentlerdeki yapıların ve altyapının yenilenmesi ihtiyacı da kentsel dönüşüm projelerinin hayata geçirilmesinde etkili olmuştur. Bu çerçevede dünyada 1900'lı yılların başında Sanayi Devrimi'nden kalan kentsel yıkıntıları gidermek, 1950-1960'lı yıllarda ise Birinci ve İkinci Dünya Savaşı'ndan kalan kentsel çöküntüleri onarmak ve kentlerin yaşanılamaz alanlarının yeniden yapılandırılarak yaşanılabilir hale getirilmesini sağlamak için kentsel dönüşüm projeleri uygulanmaya başlanmıştır. Günümüzde ise kentlerde sosyal ve ekonomik canlanmanın sağlanması ve daha güzel bir kent estetiği sağlamak amacıyla kentsel dönşüm projeleri uygulanmaktadır.

Türkiye 1950'li yıllardan itibaren hızlı kentleşme sürecine girmiş; hızlı kentleşme süreciyle birlikte sabit, yoksul ve dar gelirli vatandaşlar konut ihtiyacını gecekondular ve kaçak yapılar yaparak gidermiştir. 1950'li yıllarda yapılan gecekondular düşük kaliteli malzemeden yapıldığından büyük bir kısmı 1990'li yıllarda ekonomik ömrünü tamamlayarak içinde yaşanılamaz duruma gelmiştir. Gecekondu ve kaçak yapıların depreme dayanıksız olması, kent merkezinde kalarak kötü görünüm arz etmesi, her hangi bir deprem esnasında kaçak yapıların olduğu yerlerde diğer yerlere göre daha fazla can ve mal kaybının olması gibi nedenlerle 1980'li yılların sonundan itibaren büyükşehir belediyeler münferit olarak kentsel dönüşüm projeleri uygulamaya başlamıştır. 1990'lı yılların sonunda yaygınlaşmaya başlayan kentsel dönüşüm projeleri 2000'li yılların başında yasal (5104, 5393, 5216 Sayılı Yasalar) dayanağa kavuşturularak bütün belediyelerin kentsel dönüşüm projelerini yapma ve uygulamasının önü açılmıştır. Gelişmeler 1990'li yıllardan itibaren Türkiye'de gecekondu bölgelerinde ve kentlerdeki çöküntü alanlarında uygulamaya başlanan kentsel dönüşümm uygulamalarının zorunluluk haline geldiğini göstermektedir.

Türkiye 1950'li yıllarda hızlı kentleşme sürecine girmesine rağmen Diyarbakır 1980'li yıllarda hızlı kentleşme sürecine girmiştir. 1980’li yıllarda kırsal alandan Diyarbakır merkeze göç eden yoksul ve dar gelirli insanlar kente yerleşmek için Sur İlçesini tercih etmiş, konut ihtiyacını ise gecekondular yaparak gidermiştir. 1990'lı yıllarda giderek artan göç neticesinde Sur İlçesinin (surların) içi plansız, düzensiz, kaçak yapı ve gecekondularla dolmuştur. Plansız, düzensiz, kaçak yapılar ve gecekondulardan dolayı Sur ilçesini görünümü bozulmuş, tarihsel 
misyonu kayıp olmuş, birçok tarihi, turistik, kültürel ve antik yapıların özellikleri yok olma sürecine girmiştir. İçindeki tarihi, kültürel ve antik eserlerden dolayı açık hava muzsesi niteliğinde olan Surilçesi'ndeki bu olumsuz gelişmeler üzerine 1988 yılında Suriçi Bölgesi kentsel sit alanı olarak ilan edilmiştir. Sit alanının ilanından sonra 1990’lı yılların başında Suriçi Bölgesinin korunması için koruma imar planı yapılmıştır. Ancak koruma imar planı Suriçinde kaçak yapı ve gecekonduların yapımını önleyememiştir. Kaçak yapılar, gecekondular ve Suriçindeki tarihi, kültürel ve antik yapıların bozulan durumunun önüne geçebilmek için 2008 yılında Diyarbakır Büyükşehir Belediyesi ve TOKİ Suriçi Bölgesi için kentsel dönüşüm konusunda anlaşmış, söz konusu idareler arasında imzalanan Suriçi Kentsel Dönüşüm Protokolünün ardından Suriçinde kalan ve gecekonduların yoğun olarak içinde bulunduğu Cevatpaşa, Fatihpaşa, Alipaşa ve Lalebey Mahallelerinde kentsel dönüşüm projesi uygulanmaya başlanmıştır. Ancak 2008 yılında başlanan kentsel dönüşüm projesi kısa süreli uygulamadan sonra bazı mülk sahiplerinin uzlaşmaya varmaması üzerine 2012 yılında durdurulmuştur.

2015 yılının sonlarında başlayan 2016 yılının başlarında biten terör/güvenlik olaylarında Sur içindeki 16 mahalleden 6'sı tamamen çöküntü altında kalmış, Surların içinde bulunan ortalama 9000 yapıdan yaklaşık 3000'ni onarılacak derecede zarar görmüştür. Bu tür olumsuz gelişmelerin üzerine Bakanlar Kurulu 2016 yılında Suriçi Bölgesini acele kamulaştırma yoluna gitmiştir. Bakanlar Kurulu Kararının ardından Diyarbakır Büyükşehir Belediyesi, TOKİnin ve Çevre ve Şehircilik Bakanlığının işbirliğiyle Suriçi Bölgesinde yeniden kentsel dönüşüm uygulamalarına başlanmıştır. Kentsel Dönüşüm projesi uygulamaları çerçevesinde riskli alanda bulunan birçok riskli yapı yıkılmıştır. Çatışmalarda zarar görenlere yönelik konutlar yaptırılmış, yapımı tamamlanan konutlar hak sahiplerine kura ile teslim edilmiştir. Ayrıca konutları yıkılan, zarar gören ya da güvenlik nedeniyle konutunu terk etmek zorunda kalanlara yönelik TOKİ'nin yanısıra Çevre ve Şehircilik Bakanlığı da konut yapmaya başlamıştır. 2016 yılında ikinci kez uygulamaya konulan kentsel dönüşüp projesinin bitirilmesi için 60 aylık bir zaman süresi ön görülmüştür. Ancak ülkenin içinde bulunduğu ekonomik koşullar ve bütçeye getireceği mali yük göz önünde bulundurulduğunda Suriçi Bölgesinde uygulanan kentsel dönüşüm projesinin 60 aylık bir sürede bitirilmesinin mümkün olmadığ

Türkiye'de, başladıktan (2008) sonra durdurulan ve üzerinden neredeyse 10 yıl geçtikten sonra tekrar uygulamaya konulan (2016) ikinci bir kentsel dönüşüm projesi yoktur. Bu yönüyle Diyarbakır Sur İlçesinin kentsel dönüşüm projesi diğer kentsel dönüşüm projelerinden farklılık arz etmektedir. Ayrıca tarihi, kültürel ve antik özelliklerinden dolayı Sur ilçesinin birçok yeri 1988'de sit alanı ilan edilmiş ve bu alanda kentsel dönüşüm projesi uygulanmaktadır. Bu yönüyle de Sur İlçesinin kentsel dönüşüm projesi orijinallik arz etmektedir. Orijinalliği, ayırt edici özelliği ve öneminden dolayı Diyarbakır Sur İlçesi Kentsel Dönüşüm Projesi önemli bir uygulama olmuştur. Bütün bu gelişmelerden anlaşıldığı gibi Diyarbakır Sur İlçesi (Surlarıniçi) Kentsel Dönüşüm Projesi uygulanmadan önce Surların içindeki yapıların büyük bir kısmı kullanılamayacak ve içinde yaşanılamayacak derecede riskli duruma gelmiştir. Dolayısıyla Sur İlçesinin (Suriçi) bozulan, yıpranan, çürüyen ve yaşanılamaz duruma gelen yapıların, yıkılarak yerine çağdaş ve yaşanılabilir yeni yapıların yapılması amacıyla kentsel dönüşüm projesinin uygulanması zorunluluk haline geldiği görülmektedir. 


\section{Kaynakça}

Arslan, S.Aydın, D., Sandal, H.,\&Yarkın, G. (2016). Sur'da yıkımın iki yüzü: Kentsel dönüşüm ve abluka. Diyarbakır: Zan Vakfı Yayınları.

Aktay, Y.,Orçan, M., \&Osmanoğlu, E. (2012). Türkiye’de kentsel dönüşüm projelerinin sağllklı yürütülmesi için yöntem arayışı. TOKİ Mersin Kentsel Dönüşüm Projesi Araştırma ve Çalıştay Raporu,https://www.academia.edu/35597163/Erişim Tarihi: 25.06.2019.

Ataöv, A. (2005). Belediyelerde stratejik plan hazırlanması. Türk Belediyeler Birliği ve Konrad AdenauerStiftung,http://jfa.arch.metu.edu.tr/archive/0258-5316/2007/cilt24/sayi_2/57-82.pdf/ Erişim Tarihi: 03.04.2019.

Ataöv, A. \&Osmay, S (2007). Türkiye'de Kentsel dönüşüme yönetsel bir yaklaşım. Middle East Technical UniversityJournal Of TheFaculty Of The Architecture, 24(2), 57-82.

Ayhan, F. (2013). Kentsel dönüşüm kavramı ve tarihsel gelişimi, kentsel dönüşüm hukuku. İstanbul: İstanbul Üniversitesi Yayınları, Yayın No: 2013/1.

Aydınlı, H. İ. \&Hilal T. (2012). Kurumsal ve yasal çerçevede Türkiye'de kentsel dönüşüm. Selçuk Üniversitesi Sosyal Bilimler Enstitüsü Dergisi, 28, 61-70.

Binici, A. \&Bağlı, M. (2005). Kentleşme tarihi ve Diyarbakır kentsel gelişimi. Ankara: Bilim Adamı Yayınları.

Balamir, M. (2005). Türkiye'de kentsel iyileştirme ve dönüşüme ilişkin güncel öneri ve modeller. Mimarlık Dergisi, 322, 29-35.

Balamir, M. (2004). Aspects of Urban Regeneratıon in Turkey: The Zeytinburnu Project.The UKTurkey Urban RegenerationSymposium, Ankara.https://www.alnap.org/system/files/content/ resource/files/main/urban-regeneration-zeytinburnu-istanbul.pdf/Erişim Tarihi: 25.02.2019.

Bayraktar, E.(2006). Gecekondu ve kentsel yenileme. Ankara: Ekonomik Araştırmaları Merkezi Yayınları.

Cumhurbaşkanlığı Strateji ve Bütçe Başkanlığ1 (2019). 11. Kalkınma Planı, file://C:/Users/Casper/ Desktop/OnbirinciKalkinmaPlani.pdf/Erişim Tarihi: 18.07.2019.

Çatalbaş F.(2012). Suriçi bölgesi kentsel dönüşüm projesi ve Diyarbakır turizmine katkısı. Bozok Üniversitesi, İlahiyat Fakültesi, Dergisi,1, 45-58.

Çevre ve Şehircilik Bakanlığı-Alt Yapı ve Kentsel Dönüşüm Hizmetleri Şube Müdürlüğü, (2015). Altyap ve Kentsel Dönüşüm Hizmetlerinden Sorumlu Şube Müdürlü̈̆̈̈nün Görevleri.https:// diyarbakir.csb.gov.tr/altyapi-ve-kentsel-donusum-sube-mudurlugu-i-2710/Erişim:19.05.2019.

Çiçek, Z. A. (2007). Diyarbakır'ın fethi, tarihi ve kültürü. Diyarbakır: Söz Matbaası.

Dağtekin, E. (2018). Coğrafi işaret olarak Diyarbakır bazalt taşı ve tescili. Elektronik Sosyal Bilimler Dergisi, 66, 851-860.

Demirkıran, S. (2008). Türkiye'de Kentsel dönüşüm uygulamalarında yerel yönetimlerin rolü: Bursa büyü̈kşehir belediyesi örneği. (Yayınlanmamış Yük. Lis. Tezi). Bursa: Uludağ Üniversitesi.

Diyarbakır Büyükşehir Belediyesi (2012).15.10.2012 Tarih ve 5414 Sayll Çevre ve Şehircilik Bakanlı̆̆ına Gönderilen Yazı.http://www.hurriyet.com.tr/cevre-bakanligindan-surda-acelekamulastirma-savunmasi-8-bin-818-yapidan-907si-ruhsatli-37298847/Erişim Tarihi: 01.07.2019.

Diyarbakır Büyükşehir Belediyesi, (2011). Diyarbakır-Sur Koruma Amaçlı İmar Planı Revizyon Raporu.https://docplayer.biz.tr/10074177-Diyarbakir-kale-kenti-nde-koruma-ve-planlamasorunlari.html/Erişim Tarihi: 02.06.2019. 
Diyarbakır Büyükşehir Belediyesi, (2012). Diyarbakır Kentsel Sit Koruma Amaçlı İmar Planı Plan Açılama Raporu. https://webdosya.csb.gov.tr/db/diyarbakir/duyurular/belge --120180509155044.pdf/Erişim Tarihi: 18.05.2019.

Diy. Valiliği Çev. ve Şehircilik İl Müdürlüğü, (2019). Diyarbakır ili, Sur ilçesi sınırları içerisinde bulunan 187 hektarlık alana ilişkin, http://diyarbakir.csb.gov.tr/diyarbakir-ili-sur-ilcesi-sinirlariicerisinde-bulunan-187-hektarlik-alana-iliskin-duyuru-350805/Erişim Tarihi:12.01.2019.

Ertaş, M. (2011). Kentsel dönüşüm çalışmalarında sosyal boyutun incelenmesi: Ankara ve Londra örnekleri. Selçuk Üniversitesi Teknik Bilimler Meslek Yüksekokulu Teknik Online Dergisi, 10 (1), $1-18$.

Eşin, A. (2018). Sur'da yaşam, Emo Kadın Bülteni, 6, 16-19.

Emlakta Son Dakika (2019). Diyarbakır'da konut projeleri birer birer tamamlanıyor!, https:// www.emlaktasondakika.com/haber/genel/diyarbakirda-konut-projeleri-birer-birertamamlaniyor/142284/erişim:07.01.2019.

Genç, F. N. (2008). Türkiye'de kentsel dönüşüm: mevzuat ve uygulamaların genel görünümü. Yönetim ve Ekonomi Dergisi, 15(1), 118-119.

Gibson, M. \&Kocabaş A. (2007). Türkiye'de planlama yol ayrımında: sahte bir şafak mı yoksa yeni bir dönemin vizyonu mu? kent ve planlama: geçmişi korumak geleceği tasarlamak.(edi. Ayşegül Mengi), Ankara: İmge Kitabevi.

Görün, M. \&Kara, M. (2010). Kentsel dönüşüm ve sosyal girişimcilik bağlamında Türkiye' de kentsel yaşam kalitesinin arttırılması. Yönetim Bilimleri Dergisi, 8(2), 141-164.

Gümüşboğa, B. (2009). Katılım ekseninde kentsel dönüşüm: Altındă̆ Aktaş mahallesi örneği. (Yayımlanmamış Yüksek Lisans Tezi). Ankara: Ankara Üniversitesi Sosyal Bilimler Enstitüsü.

Haber Türk (2019). Sur ilçesindeki kentsel dönüşüm çalışmaları. https://www.haberturk.com/ diyarbakir-haberleri/63079279-yeni-diyarbakir-evlerinde-sona-gelindisur-ilcesindeki-kentseldonusum-calismalari/Erişim Tarihi: 01.08.2019.

Hürriyet (2019). Sur'da TOKİ'nin 238 konutu için kura çekildi. http://www.hurriyet.com.tr/surdatokinin-238-konutu-icin-kura-cekildi-40646170/Erişim Tarihi: 11.01.2019.

Hürriyet, (2019). 187 Hektarlık sur dönüşümü. http://www.hurriyet.com.tr /ekonomi/187-hektarliksur-donusumu-40039705/Erişim Tarihi: 25.06.2019.

İnşaat Mühendisleri Odası (2017). Kentsel dönüşüm nedir, Ankara: TMMOB Yayını.

Kalağan, G. \&Çiftçi, S. (2012). Kamu-özel sektör İşbirliğinin kentsel mekana yansıması: kentsel dönüşüm örneği ve yeni aktörler. Sosyal ve Beşeri Bilimler Dergisi,4(2), 120-134.

Karaaslan, M. (2018). Diyarbakır Suriçi bölgesinin yeniden inşası ve hukuksal boyutu. Dicle Üniversitesi Hukuk Fakultesi Dergisi, (23)39, 335-373.

Karacadağ Kalkınma Ajansı \&Diyarbakır Büyükşehir Belediyesi. (2013). SuriçiSosyo-Ekonomik Analizi Projesi, Diyarbakır: Karacadağ Kalkınma Ajansı Yayını.

Karakaş, S. Karaşin, A., Gürbüz, Ş. \&Özyılmaz, H. (2016). Diyarbakır Suriçinde Yı̆̆ma Binaların Afet Potansiyeli Bakımindan Değerlendirilmesi, TMMOB Afet Sempozyumu, Ankara, 353-373.

Kejanlı, T. \&Dinçer, İ. (2011). Diyarbakır Kale Kentin'de koruma ve planlama sorunları. Megaron Dergisi, 95-108.

Keleş, R. (1998). Kent bilim terimleri sözlüğü, Gözden Geçirilmiş 2. Baskı. Ankara: İmge Kitabevi.

Keskinok, Ç. (2001). 17 Ağustos depremi, kentleşme ve planlanma sorunları üzerine düşünceler. Planlama, 4, 33-39.

Koçak, H.\&Tolanlar, M. (2008). kentsel dönüşüm uygulamaları Aydın ve Afyonkarahisar örnekleri. Afyon Kocatepe Üniversitesi İIBF Dergisi, 2(10), 397-415. 
Kuzu, S. (2004). Özel sektör perspektifinden kentsel dönüşüm, Uluslararası Kentsel Dönüşüm Uygulamaları Sempozyumu. Küçükçekmece Belediyesi Atölye Çalışması, İstanbul, 27-30.

Mimarlık Dergisi, (2019). Kentsel dönşüm. http://www.mimarlikdergisi.com/ index.cfm?sayfa=mim arlik\&DergiSayi=413\&RecID=4348/ErişimTarihi:01.07.2019.

Nabikoğlu. A. \&Dalkılıç, N. (2013). Diyarbakır surlarının günümüzdeki durumuna yeni bir bakış. Makale Dergisi, 23-35.

Öngören, G. (2013). Kentsel dönüşüm hukuku, İstanbul: Öngören Hukuk Yayınları, Yayın No: 5.

Öngören, G. \&Çolak, N. İ. (2013). Kentsel dönüşüm hukuku-kentsel dönüşüm rehberi. İstanbul: Öngören Hukuk Yayınları.

Özden, P. (2006). Türkiye'de kentsel dönüşümün uygulanabilirliği üzerine düşünceler. İstanbul Üniversitesi Siyasal Bilgiler Fakültesi Dergisi,215-233.

Polat, S. \&Dostoğlu, N. (2007). Kentsel dönüşüm kavramı üzerine: Bursa'da kükürtlü ve Mudanya örnekleri. Uludă Üniversitesi Mühendislik ve Mimarlık Fakültesi Dergisi,1(12), 61-76.

Politeknik, (2019). Sur'da acele kamulaştırma. http://politeknik.org.tr/surda-acele-kamulastirmaoncesi-otesi-cihan-uzuncarsili-baysal/Erişim Tarihi: 18.06.2019.

Resmi Gazete, 04.11.2012 ve Sayı: 28457.

Resmi Gazete, 04.10.2016 Tarih ve Sayı: 29847.

Sami, K. (2017). Diyarbakır tarihi suriçi kentsel, mekansal ve toplumsal yaşamda renkleri yok olan kültürel miras. Uluslararası Sosyal Araştırmalar Dergisi, 53, 391-400.

Şişman, A. \& Kibaroğlu, D. (2009). Dünya ve Türkiye’de kentsel dönüşüm uygulamaları. 12. Türkiye Harita Bilimsel ve Teknik Kurultayı-Harita ve Kadastro Mühendisleri Odası, Ankara: TMMOB Yayını.

Şen, T. A. (2018). Kentsel dönüşüm uygulamalarında katılım: Samsun örneği. Selçuk Üniversitesi Sosyal ve Teknik Arasstırma Dergisi, 15, 1-24.

Tekeli, İ. (2011). Kent, kentli hakları, kentleşme ve kentsel dönüşüm. İstanbul: Tarih Vakfı Yurt Yayınları.

Toprak, Z. (2010). Yerel yönetimler. İzmir: Birleşik Matbaacılık.

TEKTAŞ (2019). Kentsel dönüşüm. https://www.tektaskentseldonusum.com/kentsel-donusum-elkitap/Erişim Tarihi: 04.08.2019.

TMMOB, (2013). Yaşanabilir kentler için kentsel dönüşüm ilkeleri. https://www.tmmob.org.tr/icerik/ yasanabilir-kentler-icin-tmmob-kentsel-donusum-ilkeleri/Erişim Tarihi: 21.02.2019.

Üstün, G. (2009). Kentsel Dönüşümün Hukuki Boyutu,İstanbul: On İki Levha Yayınları.

Yasin, M. (2006). Tarihi mekanların dönüştürülmesi sürecinde mahalli idarelerin rolü. Legal Hukuk Dergisi, 4(45), 12-25.

Yaman, M. (2014). Türkiye'de kentsel dönüşüm uygulamaları kapsamında Kütahya kenti osmangazi kentsel dönüşüm uygulamasına bir bakış. Dumlupınar Üniversitesi Sosyal Bilimler Dergisi,1(4), 12-26.

Yenice, S. (2014). Türkiye'nin kentsel dönüşüm deneyiminin tarihsel analizi. Balıkesir Üniversitesi Fen Bilimleri Enstitüsï Dergisi,16(1), 76-88.

Yıldırım, A. (2012). Diyarbakır suriçi tarihi kent bilgi sistemi önerisi. Doğu Coğrafya Dergisi, 16, 239-249

Yılmaz İ. (2015). Gecekondu direnişi: Dikmen vadisi örneği. Mülkiyet Dergisi, 309-314. 